\title{
Cooperative Field Test Program for Wind Systems
}

\section{Final Report}

\author{
D.M. Dodge \\ W.S. Bollmeier, II
}

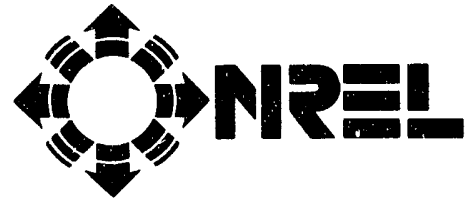

National Renewable Energy Laboratory

A Division of Midwest Research Institute

1617 Cole Boulevard

Golden, Colorado 80401-3393

Operated for the

U.S. Department of Energy

Under Contract No. DE-AC02-83CH10093

Prepared under Task Number WE129101

March 1992

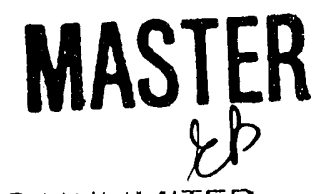




\section{Contents}

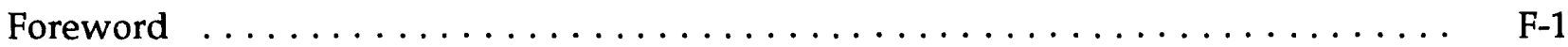

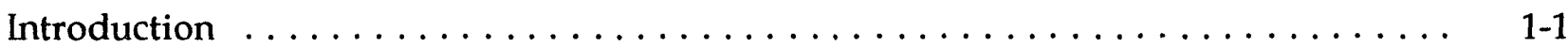

Program Description $\ldots \ldots \ldots \ldots \ldots \ldots \ldots \ldots \ldots \ldots \ldots \ldots \ldots \ldots \ldots \ldots \ldots \ldots$

Dynamic Response Tests $\ldots \ldots \ldots \ldots \ldots \ldots \ldots \ldots \ldots \ldots \ldots \ldots \ldots \ldots \ldots$ 3-1

Supporting Research Testing (Precipitation Test) $\ldots \ldots \ldots \ldots \ldots \ldots \ldots \ldots \ldots \ldots$ 4-1

Wake Measurement Tests $\ldots \ldots \ldots \ldots \ldots \ldots \ldots \ldots \ldots \ldots \ldots \ldots \ldots \ldots$ 5-1

Free-Flow Micrositing Tests $\ldots \ldots \ldots \ldots \ldots \ldots \ldots \ldots \ldots \ldots \ldots \ldots \ldots \ldots$ 6

Wind-Hybrid System Tests $\ldots \ldots \ldots \ldots \ldots \ldots \ldots \ldots \ldots \ldots \ldots \ldots \ldots \ldots \ldots \ldots$

Program Accomplishments $\ldots \ldots \ldots \ldots \ldots \ldots \ldots \ldots \ldots \ldots \ldots \ldots \ldots \ldots \ldots$ 8-1

Bibliography of CFTP Reports $\ldots \ldots \ldots \ldots \ldots \ldots \ldots \ldots \ldots \ldots \ldots \ldots \ldots \ldots$ 9-1 


\section{Foreword}

This report provides a summary of the research and test activities conducted under the U.S. Department of Energy (DOE) Cooperative Field Test Program (CFTP) with the U.S. wind industry from 1986 to 1990 . Readers interested in detailed technical information concerning the projects are directed to individual project reports listed in the bibliography.

The CFTP involved a large number of participants from industry and government; special thanks go to these people for their special contributions.

Oree Dyes of the DOE Wind/Ocean Technology Division and Steve Sargent of the DOE National Renewable Energy Laboratory (NREL) Area Office provided overall program guidance and direction.

The following industry program managers facilitated the involvement of their organizations: Mike Wehrey of Southern California Edison, John Wade of Pacific Wind Energy, Peter Liu of Flow Research Corporation, Wally Thompson of Fayette Engineering, Tom Morton and Brian Smith of Altamont Energy Corporation, Larry Van Bibber of Westinghouse, Clint (Jito) Coleman of Northern Power Systems, Mike Bergey of Bergey Windpower, and Bob Sherwin of Atlantic Orient.
The following industry technical leaders demonstrated the expertise to design and implement solid field test and research programs in the field: Peter Jamison of John Howden Ltd., Bob Baker and Stel Walker of Pacific Wind Energy, Rich Simon of Fayette Manufacturing, Ron Nierenberg of Altamont Energy, Fred Snow of Westinghouse, Brian McNiff of Northern Power Systems, and Peter Hughes of Atlantic Orient.

Bob Noun of NREL, Henry Dodd of Sandia National Laboratories, and Larry Wendall of Battelle-Pacific Northwest Laboratory (PNL) provided the DOE laboratory project teari members and technical management guidance.

The following DOE laboratory technical monitors woiked hard and diligently, often in the field for long periods: Tom Hausfeld, Rich Osgood, and Jim Tangler of NREL; and Jim Barnard, John Buck, Dennis Elliott, and Al Miller of PNL.

In addition, other team members too numerous to name here made important contributions as scientists, engineers, technicians, computer specialists, and windsmiths. Finally, thanks go to Erik Nelsen and Barbara Spitz, both of NREL, who edited the technical reports cited in the bibliography. 


\section{Introduction}

The objectives of the Federal Wind Energy Program, managed by the U.S. Department of Energy (DOE), are (1) to assist industry and utilities in achieving a multi-regional U.S. market penetration of wind systems, and (2) to establish the United States as the world leader in the development of advanced wind turbine technology.

In 1984, the program conducted a series of planning workshops with representatives from the wind energy industry to obtain input on the Five-Year Research Plan then being prepared by DOE. One specific suggestion that came out of these meetings was that the federal program should conduct cooperative research tests with industry to enhance the technology transfer process. It was also felt that the active involvement of industry in DOEfunded research would improve the state of the art of wind turbine technology. DOE established the Cooperative Field Test Program (CFTP) in response to that suggestion. This program was one of the first in DOE to feature joint industrygovernment research test teams working toward common objectives. 


\section{Program Description}

\section{Program Objectives and Approach}

The primary objective of the CFTP was to obtain wind turbine machine and site data for use in (1) exercising and validating analytical codes developed under the Federal Wind Energy Program and (2) assisting industry in formulating and validating solutions to specific technical problems. The general approach was to conduct cooperative research tests with industry participants, which were competitively selected beginning in September 1985, following a general solicitation to industry.

Specific research areas in which data and information were solicited included those identified in the Five-Year Research Plan for the period 1985-1990: atmospheric fluid dynamics, aerodynamics, structural dynamics, and supporting research (such as electrical system harmonics and turbine acoustics).

Proposals were solicited in 1985 under five test categories, which represented the research and test data needs of the federal program and industry that had been identified during the development of the FiveYear research plan. These categories were:

- Dynamic response tests

- Wake measurement tests

- Local flow measurement for micrositing

- Loading spectra measurement for fatigue damage

- Supporting research testing.

During the first round of the CFTP, projects in the first three categories and the last category were selected. The loading spectra measurement test project with Northern Power Systems was conducted subsequent to the first-round projects.
The second round of the collaborative efforts with industry was called the Cooperative Research Program (CRP). The solicitation for this program was developed in 1987. The overall objectives of the program did not change. However, the categories in which research was solicited were different. The CRP categories were:

- Wind-Hybrid system tests

- Wind-Electric water pumping

- Ridgeline terrain effects on micrositing of wind farms

- Macroscale effects in siting of wind farms

- Other related research activities.

Two agreements in category one and one agreement in category two resulted from the selection process. No agreements resulted from the other three categories. The projects and industry participants in the CFTP, together with agreement award dates and DOE funding and cost-shared amounts, are listed in Table 1.

\section{Program Management}

The CFTP was managed through the joint efforts of the DOE Wind/Ocean

Technology Division, which provided overall programmatic guidance and coordinated the efforts of the field organizations; the National Renewable Energy Laboratory (NREL), which coordinated and performed technical monitoring of the projects, along with Pacific Northwest Laboratory (PNL), and Sandia National Laboratories; and the DOE NREL Area Office, which provided field management of the program, including issuing and evaluating the program proposals, and letting and administering the resulting cooperative agreements. 


\section{Program Description}

\begin{tabular}{|c|c|c|c|c|c|}
\hline \multirow[t]{2}{*}{ Industry Participant } & \multirow[t]{2}{*}{ Project } & \multirow[t]{2}{*}{ Award Date } & $\begin{array}{l}\text { DOE } \\
\text { Share }\end{array}$ & $\begin{array}{c}\text { Industry } \\
\text { Share }\end{array}$ & \multirow[t]{2}{*}{ Total } \\
\hline & & & \multicolumn{2}{|c|}{$(\$ \times 1000)$} & \\
\hline Southern California Edison & Dynamic Response Test & $09-27-85$ & 65.0 & 65.0 & 130.0 \\
\hline Pacific Wind & Precipitation Effects & $12-02-85$ & 28.8 & 41.0 & 69.8 \\
\hline Pacific Wind & Micrositing Study & $12-02-85$ & 28.9 & 41.0 & 69.9 \\
\hline Fayette Manufacturing & Wake Study & $12-20-85$ & 73.0 & 57.0 & 128.0 \\
\hline Flow Manufacturing & VAWT Wake Study & $01-07-86$ & 95.0 & 70.0 & 165.0 \\
\hline Altamont Energy & Wake Study & $01-07-86$ & 85.0 & 105.0 & 190.0 \\
\hline Altamont Energy & Micrositing Study & $01-07-86$ & 80.0 & 105.0 & 185.0 \\
\hline Westinghouse & Dynamic Response Test & $04-15-86$ & 99.9 & 129.0 & 228.9 \\
\hline Northern Power Systems & Dynamic Response Test & $09-30-86$ & 100.0 & 149.0 & 249.0 \\
\hline Northern Power Systems & Fatigue Test & $03-12-87$ & 160.0 & 144.3 & 304.3 \\
\hline Northern Power Systems & Wind-Diesel Tests & $08-07-87$ & 100.0 & 170.8 & 270.7 \\
\hline Bergey Windpower & Water Pumping Test & $08-25-87$ & 99.7 & 97.9 & 197.6 \\
\hline \multirow[t]{2}{*}{ Atlanta Orient } & Wind-Diesel Test & $09-10-87$ & 81.1 & 58.4 & 139.5 \\
\hline & & Totals & 1096.4 & 1232.4 & 2230.6 \\
\hline
\end{tabular}

Table 1. Cooperative Research Program Industry Participants 


\section{Dynamic Response Tests}

The primary objective of dyramic response tests was to measure the wind input to the rotor and the resulting aerodynamic and structural responses for a variety of wind turbines in different wind regimes. A secondary objective was to investigate actual operation problems experienced in a wind farm environment. DOE was interested primarily in the first objective because of the need for accurate machine data sets to exercise and validate analytical design tools. Industry participants had more interest in the second objective because they had specific concerns relative to their machine designs. In addition, each participant had developed or adapted its own analytical model to predict dynamic response, which it sought to test or verify' using CFTP data.
Three dynamic response tests were conducted of three different wind turbines. The output of the test machines ranged from $100 \mathrm{~kW}$ to $600 \mathrm{~kW}$ and represented several different design approaches (see Table 2). The machines were located in three different high-wind regimes, including a marine trade winds site with complex terrain and two inland sites: one with simple (flat) terrain and the other with complex terrain. The participants included Westinghouse Corporation, Northern Power Systems (NPS), and Southern California Edison (SCE), which collaborated with James Howden and Company, Ltd. of Great Britain.

Instrumentation used to collect and record data for analysis was similar for all three

\begin{tabular}{|l|c|c|c|}
\hline \multirow{2}{*}{ Design Feature } & \multicolumn{3}{|c|}{$\begin{array}{c}\text { Participant } \\
\text { (Manufacturer) }\end{array}$} \\
\cline { 2 - 4 } & SCE (Howden) & Westinghouse & Northern Power \\
\hline \hline Rated Output $(\mathrm{kW})$ & 330 & 600 & 100 \\
\hline Rated Windspeed $(\mathrm{m} / \mathrm{s} ; \mathrm{mph})$ & $14.5 ; 32.3$ & $14 ; 31.2$ & $14 ; 31.2$ \\
\hline Rotor Diameter $(\mathrm{M} ; \mathrm{ft})$ & $26 ; 82$ & $43.9 ; 142$ & $17.8 ; 58.3$ \\
\hline Configuration & Upwind & Upwind & Upwind \\
\hline Number of Blades & Three & Two & Two \\
\hline Type Hub & Rigid & Teetered & $\begin{array}{c}\text { Teetered with } \\
\text { offset }\end{array}$ \\
\hline Blade Construction & Wood Composite & Wood Composite & $\begin{array}{c}\text { Fiberglass } \\
\text { Composite }\end{array}$ \\
\hline Airfoil & GA(W)-1 & LS-1 & NACA 44-XX \\
\hline Rotor Control & $\begin{array}{c}\text { Fixed Pitch/ } \\
\text { Movable Tips }\end{array}$ & $\begin{array}{c}\text { Active/Full-Span } \\
\text { Pitch to Feather }\end{array}$ & $\begin{array}{c}\text { Passive/Full Span } \\
\text { Pitch to Feather }\end{array}$ \\
\hline Yaw Control & Active Yaw Drive & Active Yaw Drive & Passive Yaw Drive \\
\hline
\end{tabular}

Table 2. Comparison of Wind Turbine Design Features 


\section{Dynamic Response Tests}

tests. Primary data were FM-multiplexed and recorded in analog form on tape recorders for later digitization on a NEFF 720 system at NREL. In parallel with this, a Mid-Scale Data Acquisition System was used to provide "quick-look" capability while the test was running. This system included a Compaq 286 or 386 personal computer, using Labtech Notebook software and Keithly data-acquisition hardware (see Figure 1).

\section{Southern California Edison/Howden}

The 330-kW Howden wind turbine tested under this project was located at the SCE test site in the San Gorgonio Pass, Calif., near several heavily developed wind farm sites. A vertical plane array of anemometers was installed immediately upwind of the three-blade, rigid-hub test machine. The test configuration is depicted in Figure 2.

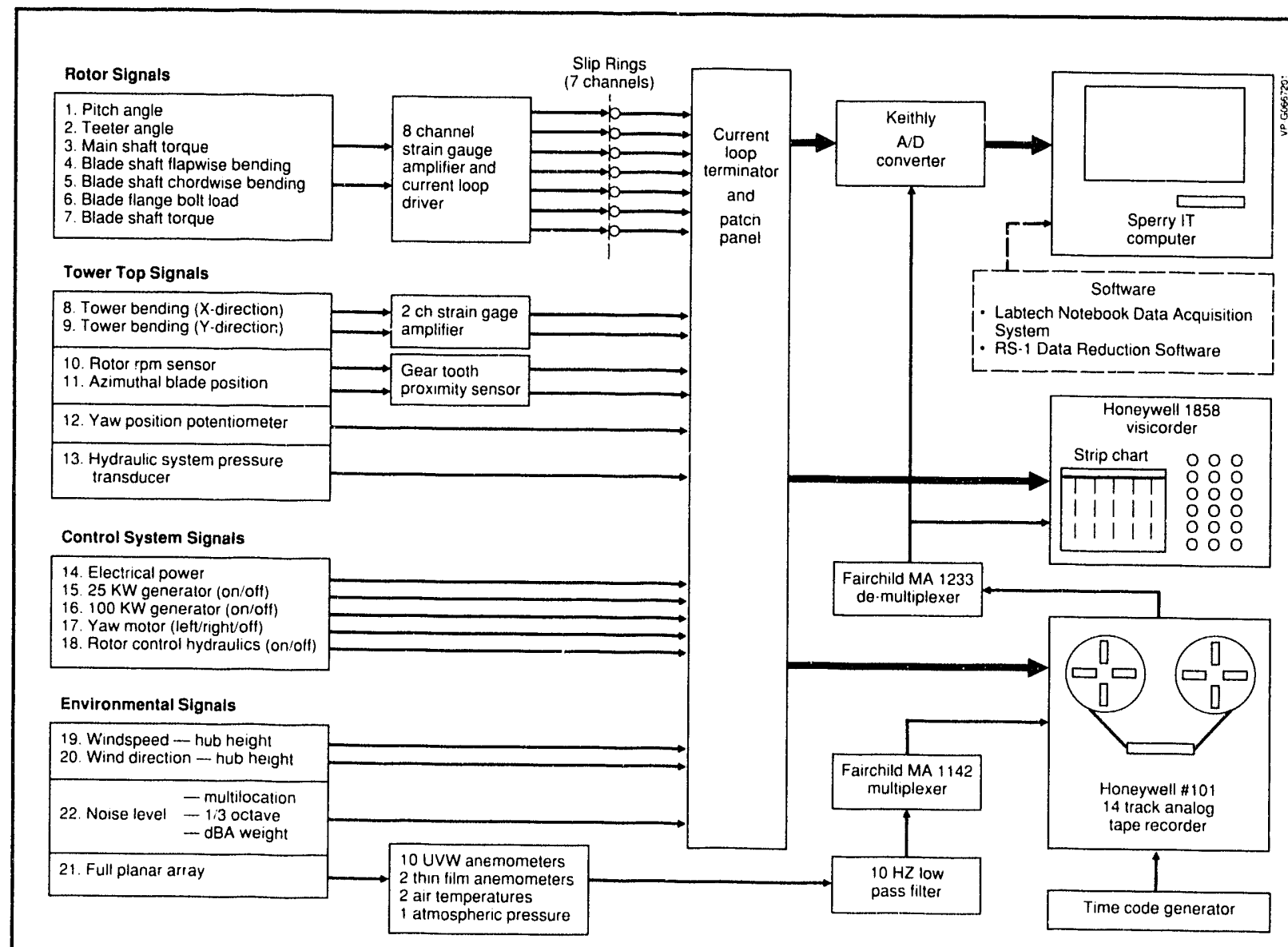

Figure 1. Mid-Scale Data Acquisition System 


\section{Dynamic Response Tests}

\section{Test Results}

Twenty-two hours of high-quality engineering data were collected, including wind characteristics, blade cyclical loads, tower loads, yaw system loads, and power output. Some flow visualization of the near-blade boundary layer was also performed, using tufts mounted on the blades.

Measured blade mean bending loads were generally $15 \%$ more (with a high range from $67 \%$ to $27 \%$ ) than predicted by the code used by Howden in designing their wind turbine. In addition, although power output generally agreed with Howden predictions, there was a rounding of the power curve coincident with power limiting. It was concluded that these effects are due to the inability of the blade tip sections to maintain optimum power under unsteady aerodynamic conditions (turbulence). This is shown in Figure 3.

The high quality of the machine and anemometer data collected under this project and the correlation of wind input with machine loads and performance have made it excellent for use in

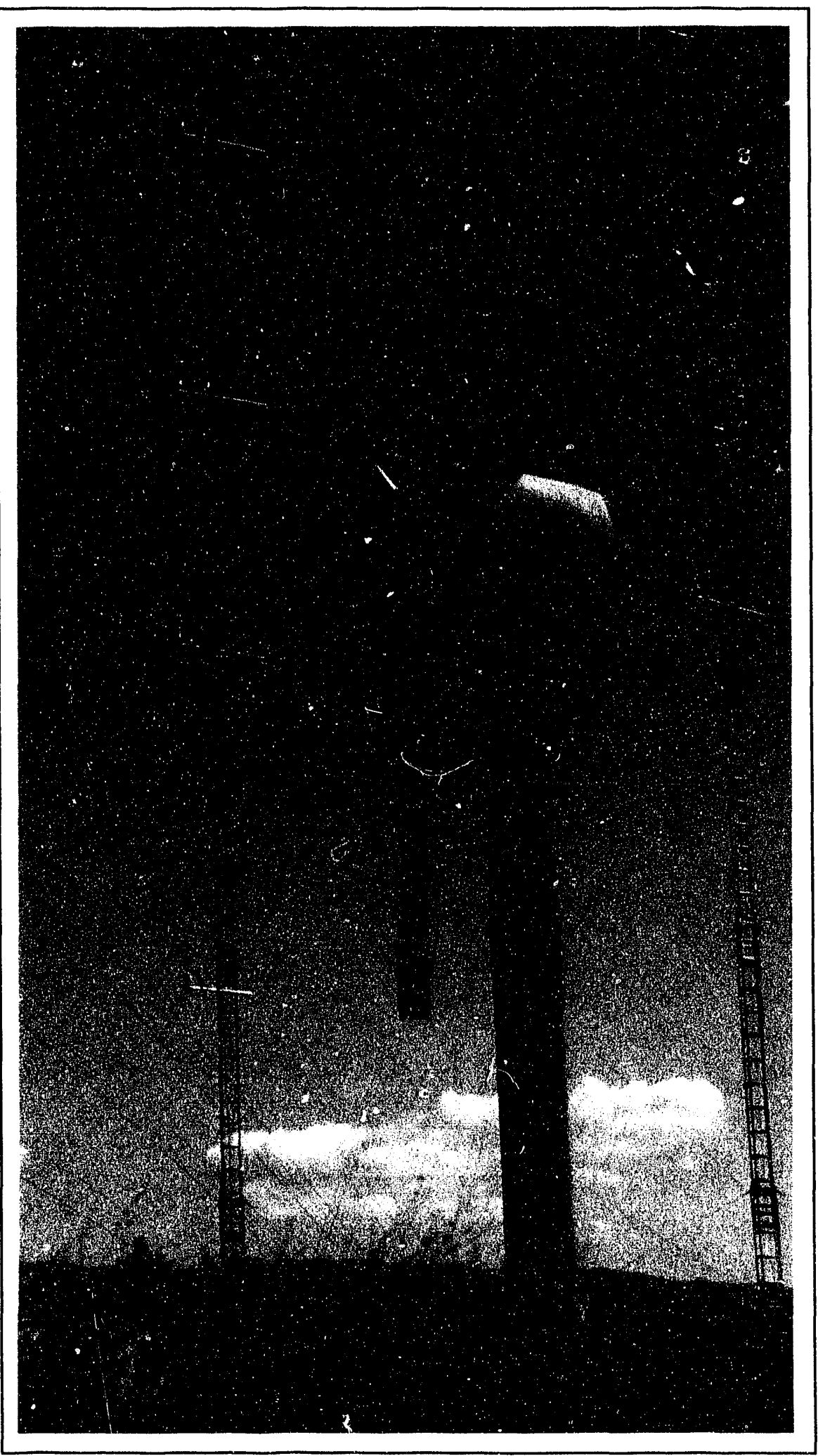

Figure 2. SCE - Howden 330-kW wind turbine 
validating predictive codes. This has already been done at NREL (for structural dynamics codes), the University of Utah (for yaw dynamics codes), and Oregon State University (for turbulence models).

\section{Westinghouse Corporation}

The $600-\mathrm{kW}$ Westinghouse test turbine was located in a 15-unit wind farm near the north shore of the Island of Oahu, Hawaii (see Figure 4). Hawaii is dominated by trade winds, but the hilly coastal terrain generates relatively high turbulence levels in the vicinity of the wind farm. The test machine was mounted on a tube tower and incorporated a two-blade, upwind rotor with a teetering hub. The blades were equipped with vortex generators. Meteorological measurements were made on a single tower to provide data suitable for a PNL-developed, single tower, rotationally sampled wind measurements analysis technique (STRS2).

\section{Test Results}

Twenty-six hours of data were collected. While these data were contaminated by a $1.2 \mathrm{~Hz}$ signal due to a malfunction in the FM tape recorder, many of the analog signals were sufficiently strong to permit definition despite the interference. Other signals were digitized in real-time by the

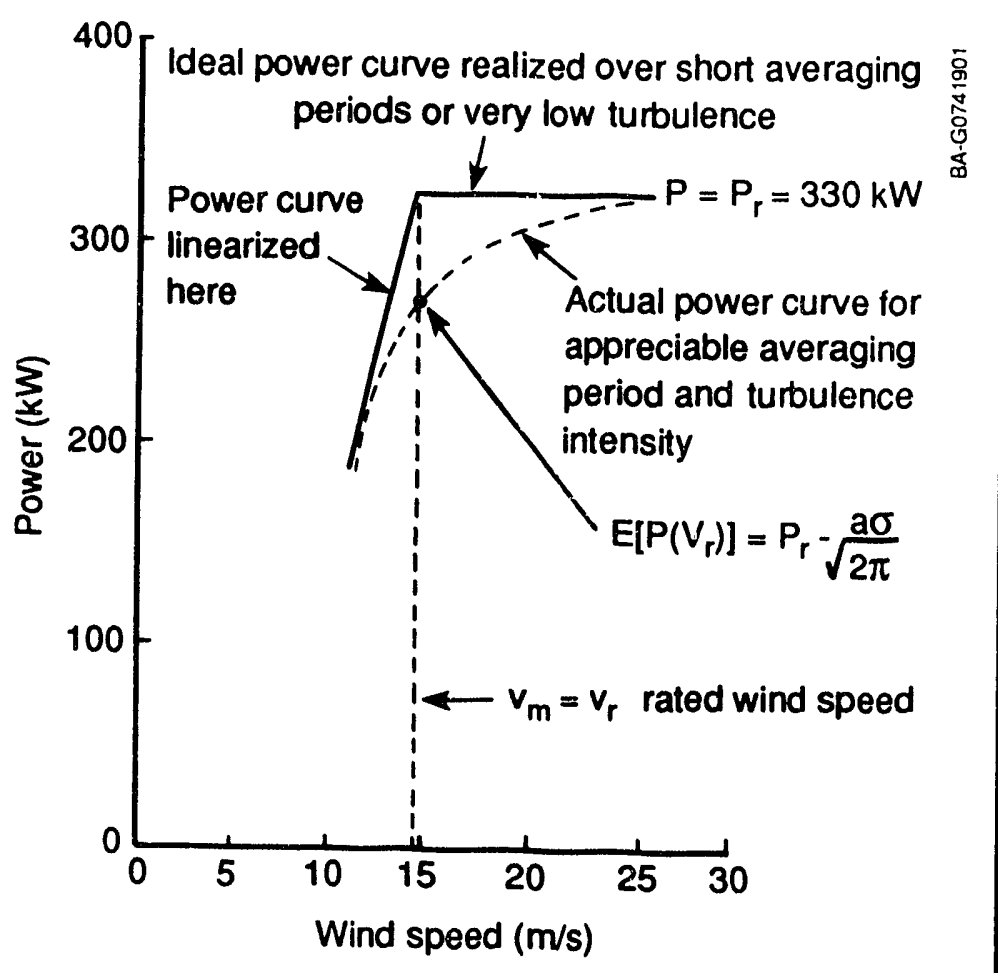

Figure 3. Effect of turbulence on power output (Howden 330-kW wind turbine)
Mid-Scale Data Acquisition System and are free of contamination. The data documents blade meanloads, blade cyclical loads, and power output performance in winds of $15 \mathrm{mph}$ to more than $40 \mathrm{mph}$.

Westinghouse concluded that blade bending load results indicate that current methods of determining blade flapwise cyclical bending moments may not be sufficiently conservative to provide a factor of safety. 


\section{Dynamic Response Tests}

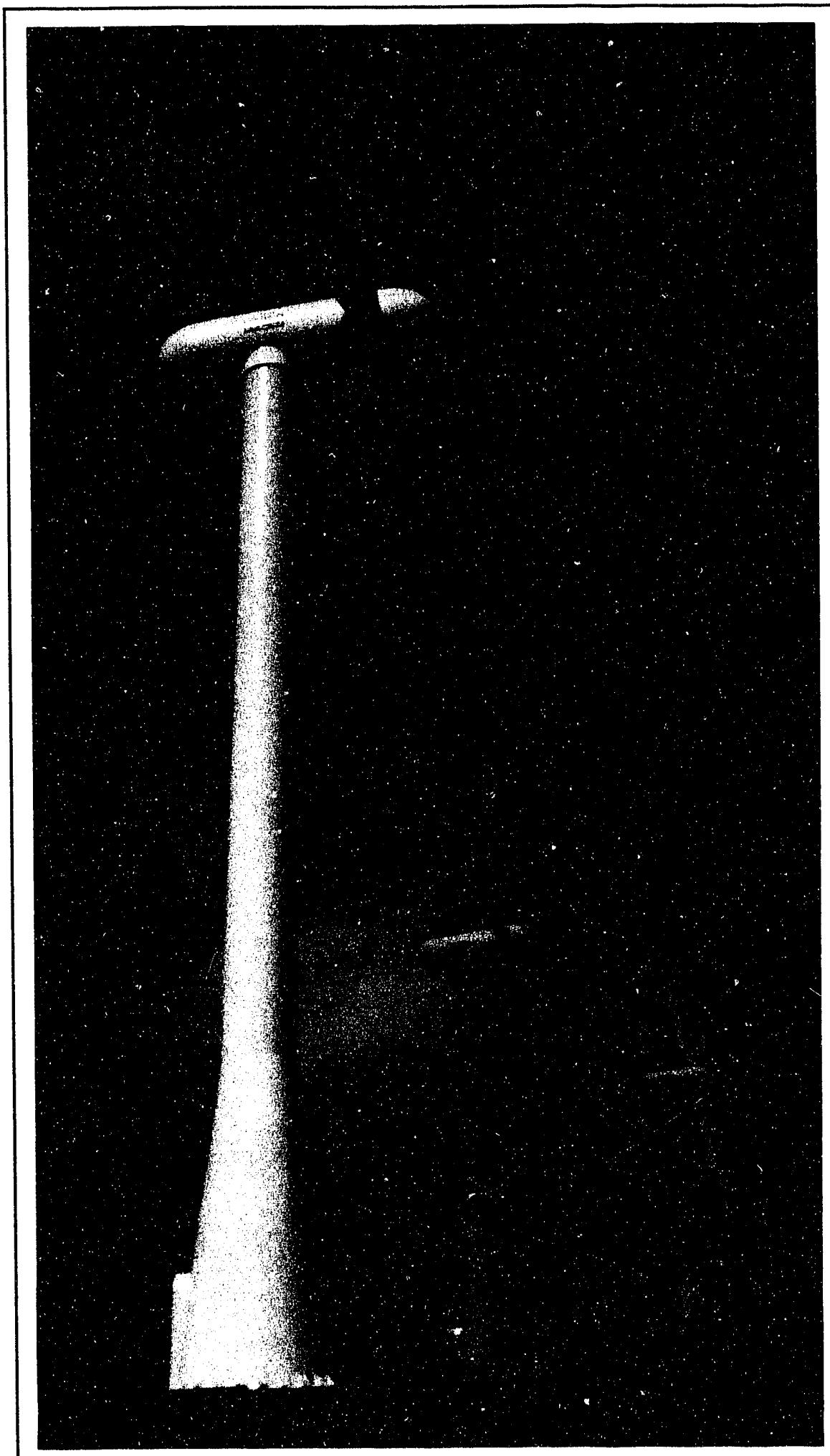

Figure 4. Westinghouse $600-\mathrm{kW}$ wind turbine
A rainflow-analogy, cyclecounting technique was used to calculate the number of fatigue cycles over the load range. The results indicated onehalf cycle with a moment range of $82,000 \mathrm{ft}-\mathrm{lb}$, compared with a predicted value of 22,200 ft-lb using an aeroelastic analysis that incorporates steadystate aerodynamics and a simple turbulence model. Subsequent analysis at NREL indicated a maximum cyclical moment of $100,000 \mathrm{ft}-\mathrm{lb}$, almost five times the predicted value.

\section{Northern Power Systems}

The NPS test turbine was nominally rated at $100 \mathrm{~kW}$ but was capable of producing more than $125 \mathrm{~kW}$ at and above its rated speed of $29.7 \mathrm{mph}$. This was the most unconventional of the three machines tested, utilizing a flapping and teetering two-blade rotor designed to minimize cyclical fatigue loads. The turbine was located on a ridge in the Altamont Pass wind farm area (see Figure 5). In this area, high winds are created in the summer months when hot air rises from the inland valley floor, allowing an inrush of cool, dense marine air over low coastal hills. 


\section{Dynamic Response Tests}

This test used a vertical plane array of anemometry to obtain detailed wind characteristics data for correlation with rotor loading.

During test preparations, a modal vibration test performed by NREL identified a potentially dangerous once-per-revolution (1P) rotor excitation of the first-bending natural frequency of the tower. The tower was subsequently stiffened by NPS using metal guy rods to avoid this effect.

\section{Test Results}

Eighty-four hours of test data were collected under a wide spectrum of wind conditions: from $10 \mathrm{mph}$ to more than $40 \mathrm{mph}$.

Data include information on wind characteristics, blade mean loads, cyclical loads, yaw system loads, and power output. The fact that the design configuration of the $t \in s t$ machine was not fixed required the use of special operating conditions. For example, yaw control difficulties required the turbine to be locked

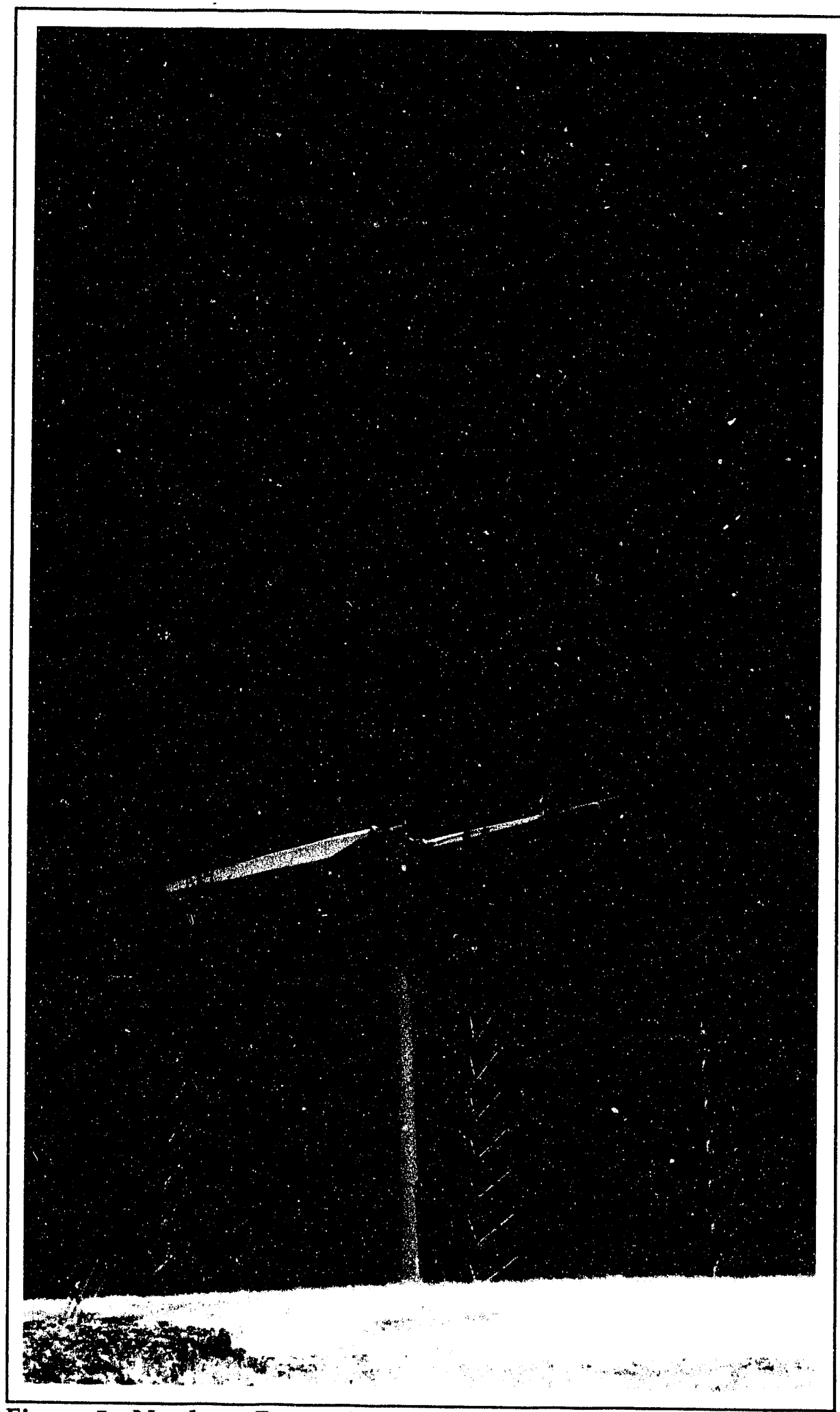

Figure 5. Northern Power Systems' NorthWind 100 wind turbine 


\section{Dynamic Response Tests}

in yaw during performance tests. However, the high-quality blade load and wind characteristics data have proved to be highly useful for comparisons of the flexible NPS rotor with rigid rotor designs. The test data have also proven to be highly useful to NPS in understanding and modifying the behavior of the unique NorthWind 100 rotor system.

Measured blade mean loads were generally as predicted by NPS However, the blade edgewise loads did not increase with increased torque levels, as expected, possibly due to centrifugal stiffening effects, which were not adequately accounted for in the prediction model. Blade cyclical loads (see Figure 6) are provided in plots of bending moments as a function of the blade azimuth position. The effect of cross flow on the blade is seen as an increased bending moment during the advancing quarter and a slightly decreasing moment in the retreating quarter. The mean data points were developed from $80 \mathrm{~min}$ of data, providing a high degree of statistical confidence.

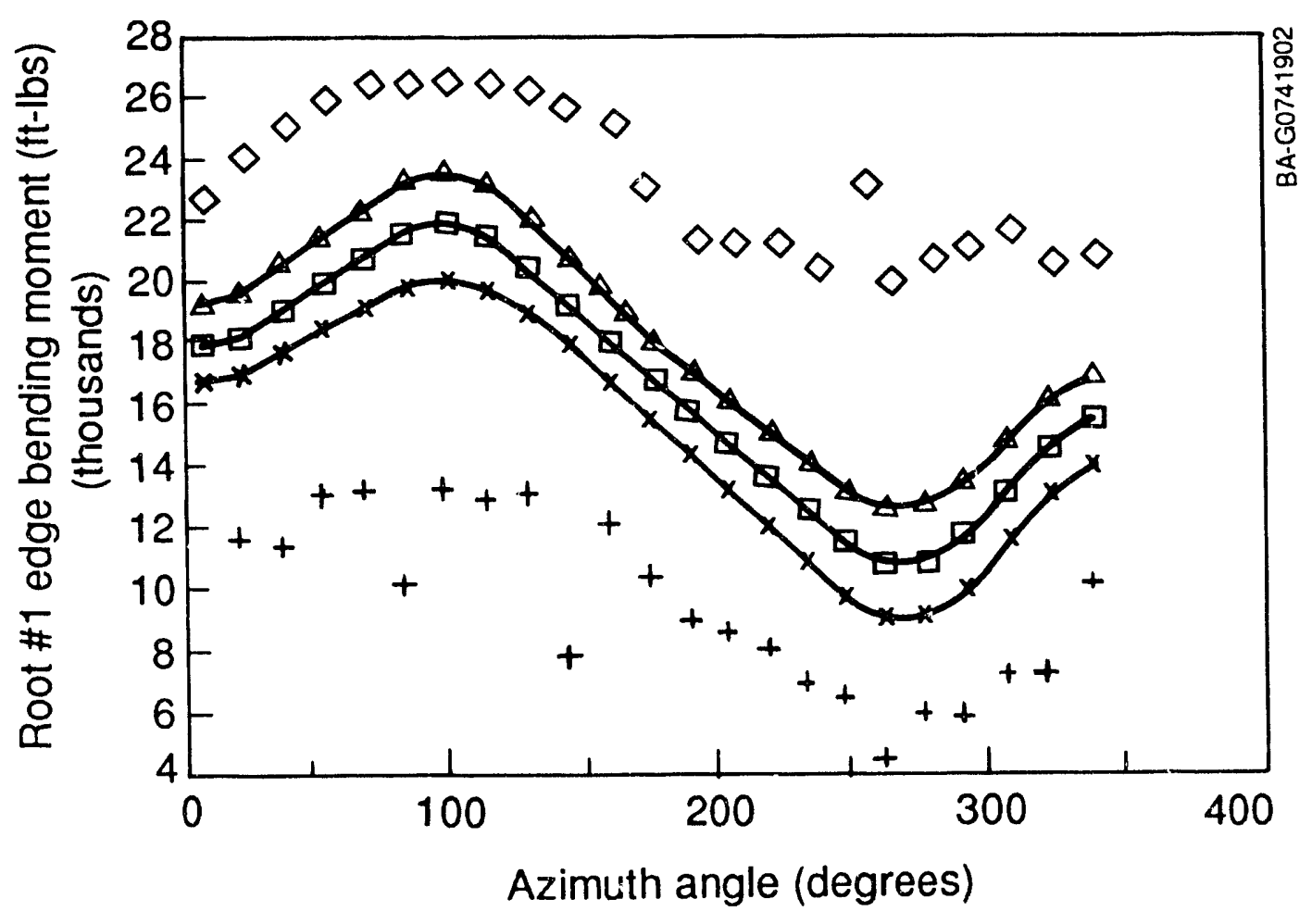

aMean tMin. $\diamond$ Max. $\Delta$ Mean + SD $x$ Mean $-S D$

Figure 6. NPS blade cyclical load data 


\section{Dynamic Response Tests}

\section{Conclusions of Dynamic Response Tests}

The most significant finding of the machine tests was the experimental confirmation of the importance of nonsteady-state conditions in wind turbine loading and performance prediction. Each participant attempted to predict blade loads with analytical tools based on steady-state aerodynamics. Very few of the predictions were within $25 \%$ of the actual loads measured. The participants generally agreed that the inaccuracy of predictions was due to the unmodeled effects of turbulent inflow.

By 1985, the accepted wind inflow model had evolved as shown in Figure 7.

Because of this evolution, some effects of turbulence were expected. But the measurements were among the first to demonstrate the magnitude of unsteady aerodynamic effects and the importance of including them in predictive computer codes.
Because performance data were collected while the machines were sustaining measured high turbulence levels during some test periods and an accurate multi-sensor anemometer was used, the data are highly useful for assessing the predictive accuracy of new analytical models that incorporate non-steady aerodynamic conditions.

The tests resulted in the acquisition of sizable data sets summarized in Table 3 . The data collected under the three machine tests are difficult to compare directly without manipulation because of the different turbine sizes and the different sites at which they were located. Careful normalization of the Howden and NPS data corroborates an apparent trend of lower blade loading for the more flexible NPS turbine.

In 1988, researchers at NREL established that the teetered-rotor design of a flexible rotor wind turbine produced lower dynamic blade flapping moments than a

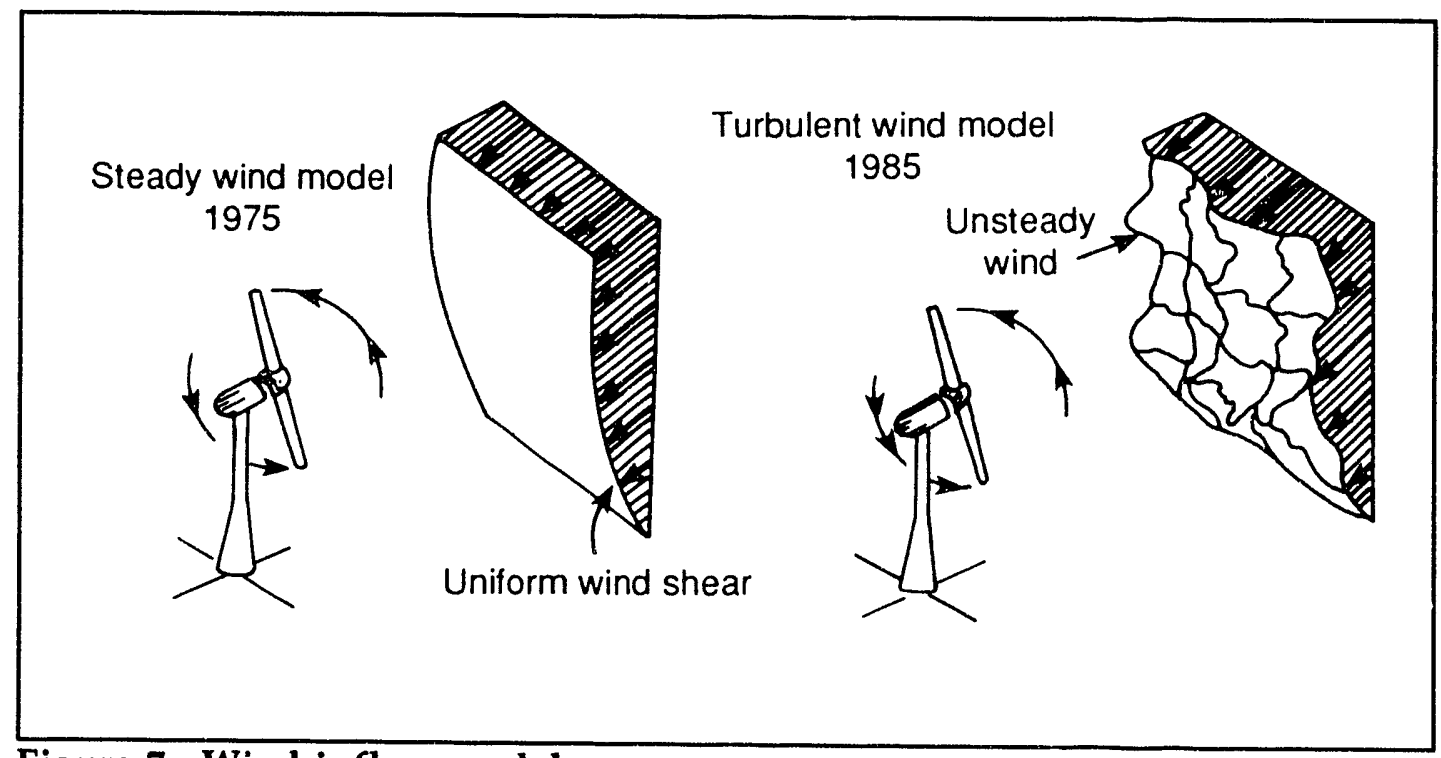

Figure 7. Wind inflow model 
Dynamic Response Tests

\begin{tabular}{|c|c|c|c|}
\hline \multicolumn{4}{|c|}{ Number of Channels Measured } \\
\hline Test Parameter & SCE (Howden) & Westinghouse & Northern Power \\
\hline $\begin{array}{l}\text { Blade Loads } \\
\text { Flapwise } \\
\text { Edgewise } \\
\text { Torsion } \\
\text { Fatigue } \\
\text { Other }\end{array}$ & $\begin{array}{l}4 \\
4 \\
0 \\
0 \\
\frac{3}{11} \\
\end{array}$ & $\begin{array}{l}6 \\
0 \\
0 \\
0 \\
\frac{6}{12} \\
\end{array}$ & $\begin{array}{l}5 \\
4 \\
1 \\
2 \\
\frac{1}{13} \\
\end{array}$ \\
\hline $\begin{array}{l}\text { Rotor } \\
\text { Azimuthal Position } \\
\text { Blade Pitch Angle } \\
\text { Teeter Angle } \\
\text { Shaft Torque } \\
\text { RPM } \\
\text { YAW Position } \\
\text { Yaw Torque Subtotal: }\end{array}$ & $\begin{array}{l}1 \\
0 \\
0 \\
0 \\
1 \\
2 \\
1 \\
5\end{array}$ & $\begin{array}{l}1 \\
1 \\
1 \\
0 \\
1 \\
2 \\
\frac{0}{6}\end{array}$ & $\begin{array}{l}1 \\
1 \\
1 \\
1 \\
1 \\
1 \\
1 \\
7\end{array}$ \\
\hline $\begin{array}{l}\text { Tower Loads } \\
\text { Bending } \\
\text { Axial } \\
\text { Torsion/Hoop } \\
\end{array}$ & $\begin{array}{l}1 \\
0 \\
0 \\
1\end{array}$ & $\begin{array}{r}7 \\
2 \\
\frac{3}{12} \\
\end{array}$ & $\begin{array}{l}2 \\
0 \\
\frac{0}{2}\end{array}$ \\
\hline $\begin{array}{l}\text { Nacelle } \\
\text { Electrical Power } \\
\text { Hydraulic System } \\
\text { Acceleration } \\
\text { Bedplate Loads } \\
\quad \text { Subtotal: }\end{array}$ & $\begin{array}{l}1 \\
0 \\
2 \\
\frac{0}{3}\end{array}$ & $\begin{array}{l}1 \\
0 \\
3 \\
\underline{6} \\
10 \\
\end{array}$ & $\begin{array}{l}2 \\
2 \\
2 \\
0 \\
6\end{array}$ \\
\hline $\begin{array}{l}\text { Meteorological } \\
\text { Wind Speed } \\
\text { Wind Direction } \\
\text { Amb. Temperature } \\
\text { Amb. Humidity } \\
\text { Amb. Pressure Subtotal: }\end{array}$ & $\begin{array}{r}31 \\
1 \\
1 \\
0 \\
\frac{1}{34}\end{array}$ & $\begin{array}{r}18 \\
1 \\
2 \\
1 \\
\frac{1}{23}\end{array}$ & $\begin{array}{r}47 \\
3 \\
2 \\
0 \\
\frac{1}{53}\end{array}$ \\
\hline Total & 54 & 63 & 81 \\
\hline
\end{tabular}

Table 3. Summary of Data Collected During Dynamic Response Tests 


\section{Dynamic Response Tests}

typical rigid-rotor design. The analysis (using the excellent data sets obtained during the CRP) demonstrated that rigidrotor designs emphasize harmonics associated with blade passage. In Figure 8 , it can be seen that the blade-bending response of the rigid-rotor is an order of magnitude higher than that for the flexible rotor system.
The majority of the energy content for both systems is in the less-damaging (from a fatigue cycle standpoint), low-frequency end of the spectrum, but this is especially true for the flexible rotor. Tower loads are also significantly lower for the flexible system (Hock, Thresher, and Wright 1989).

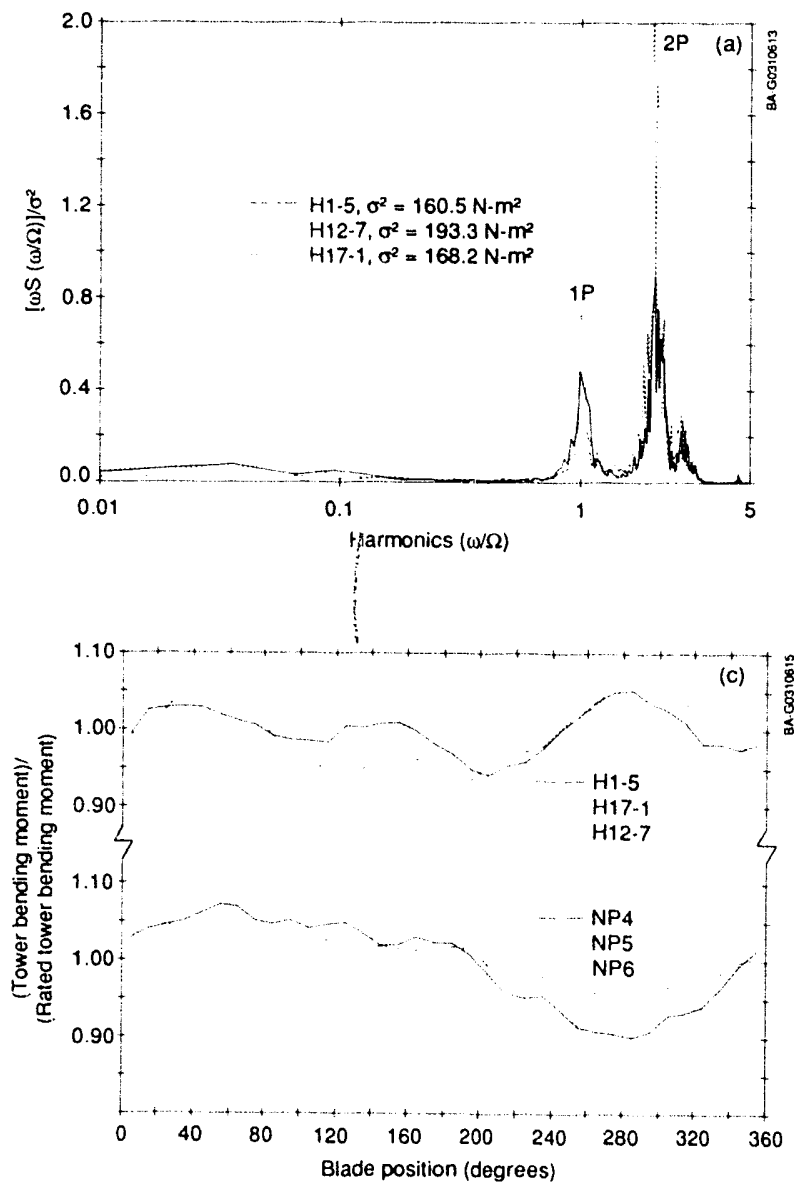

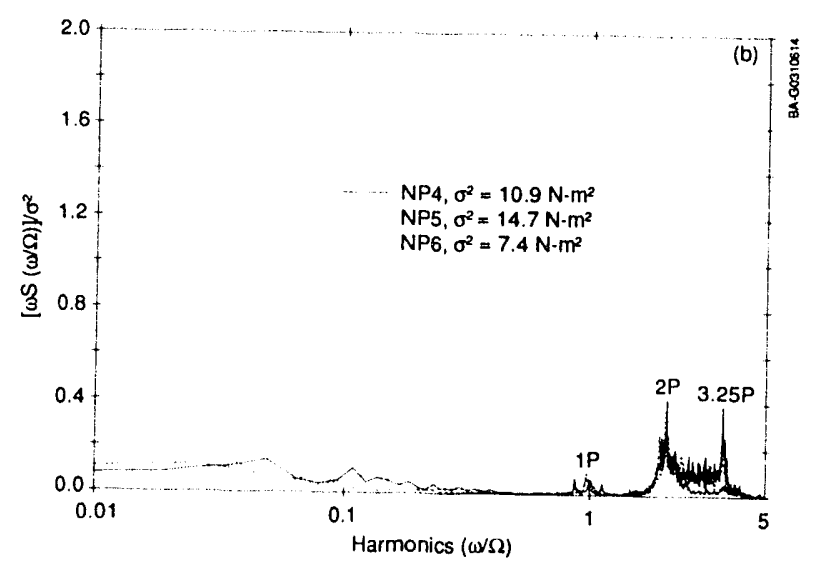

Figure 8. Dynamic load comparison for rigid and flexible rotor systems.

(a) Reduced normalized spectra of the stochastic root flapwise bending moments for the Howden data sets, (b) reduced normalized spectra of the stochastic root flapwise bending moments for the Northern Power Systems data sets, (c) normalized azimuth-averaged tower bending moments for the Howden and Northern Power Systems data sets. 


\section{Supporting Research Testing (Precipitation Test)}

The single supporting research test conducted was a measurement of the effects of precipitation on wind turbine performance by Pacific Wind Energy. This subject was of interest because developers feared a large drop in the annual energy output of wind farms at sites with large amounts of rain. Previous measurements of the 125-ft diameter MOD-0 100-kW wind turbine (Corrigan and DeMigiio $1985)^{*}$ indicated an $18 \%$ decrease in performance for light rain (less than $20 \mathrm{~mm}$ / $\mathrm{hr}$ ), and a $25 \%$ decrease for heavy rain (more than $30 \mathrm{~mm} / \mathrm{hr}$ ). These results were questioned by research:ers because the instrumentation did not separate the effects of rainfall from potential turbulence effects. Pacific Wind Energy tested 4 of the 24 ESI-54 wind turbines installed at the Whisky Run wind farm on the southwest Oregon coastline (see Figure 9). The specific objective was to obtain detailed performance data stratified with respect to the rate of rainfall, turbulence intensity, and atmospheric stability for correlation with performance models and other data sets on the NACA 23000 airfoil cross section used on both the MOD-0 and the ESI-54.

The ESI-54 wind turbine used for this test is a two-blade downwind machine rated at $56 \mathrm{~kW}$ with a rotor diameter of $54 \mathrm{ft}$.

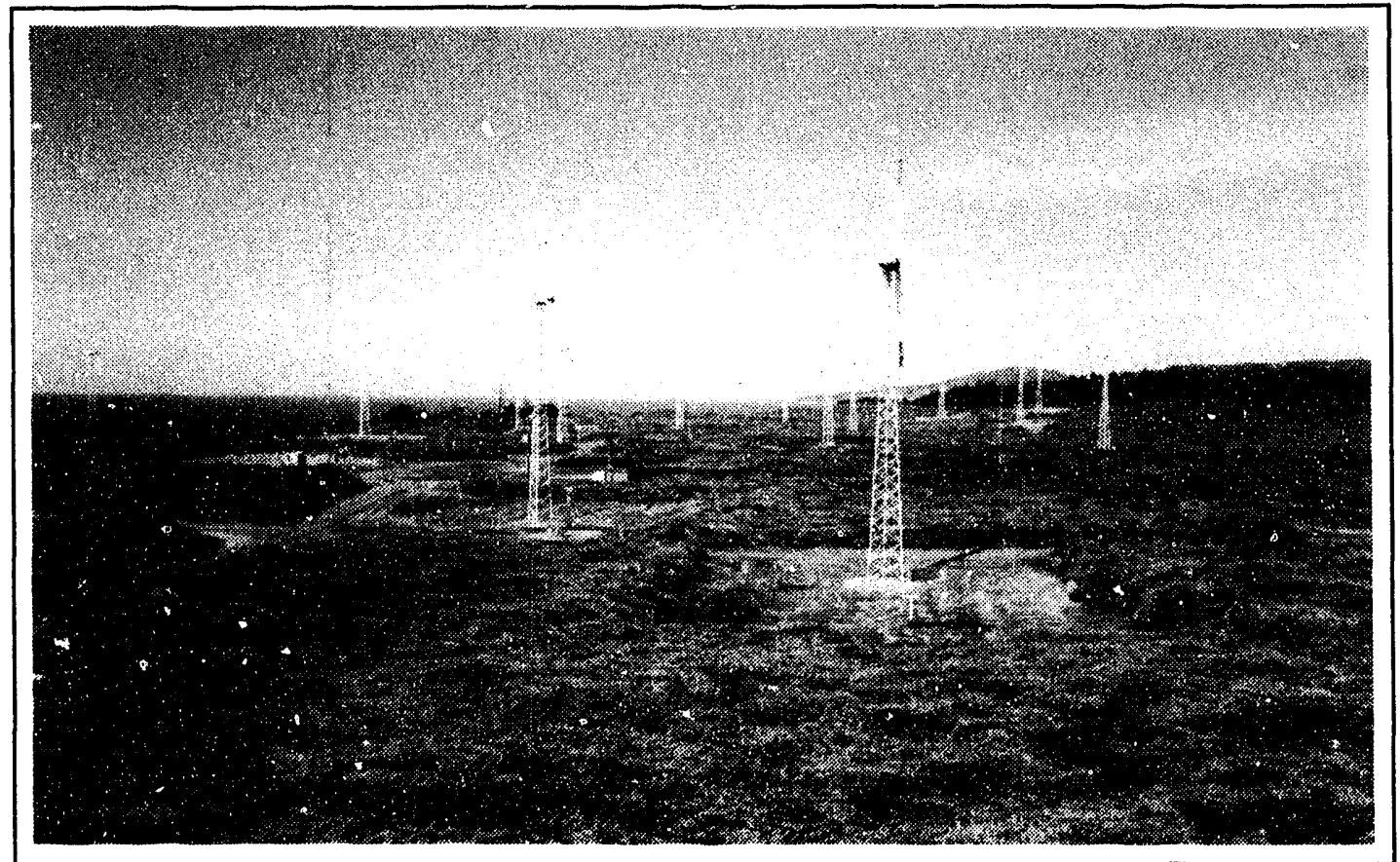

Figure 9. Precipitation test site - Whiskey Run wind farm

*Corrigan, R. D. and R. D. DeMiglio (1985), Effect of Precipitation on Wind Turbine Performance, 4th ASME Conference Proceedings, Dallas, Tex. 


\section{Supporting Research Testing (Precipitation Test)}

Test Results

Data were acquired during autumn, winter, and spring (February through April 1986 and October 1986 through April 1987). Rainfall was generally light (less than $20 \mathrm{~mm} / \mathrm{hr}$ ) and no heavy rainfall was experienced. Under these conditions, this test showed a slight increase in performance of approximately $3 \%$, contradicting the earlier National Aeronautics and Space Administration study (at least for the ESI-54). Researchers concluded that, for this wind turbine, light rain actually enhances performance, perhaps by reducing blade roughness (due to insect accumulation or soiling) or improving other aerodynamic characteristics of the blade surface. 


\section{Wake Measurement Tests}

A good scientific understanding of wind turbine wakes is necessary for the formulation of analytical tools to maximize wind farm annual energy capture and reduce fatigue damage caused by the wake velocity deficiency and high turbulence in wind farms.

Developers have sometimes installed wind turbines in tightly spaced rows (in some cases, as close as $2 \times 7$ rotor diameters), to maximize the use of available land. There is concern about the effects of this tight spacing, but little engineering data exist to support the use of wider turbine spacing. The objective of CFTP wake measurements was to provide this basic data.
Wake effect measurements were made at three different sites, one at Tehachapi and two in the Altamont Pass area. Measurements were made in three arrays, incorporating three different wind turbine designs: one vertical axis wind turbine (VAWT) (FloWind $150 \mathrm{~kW}$ ) and two horizontal axis wind turbines (HAWTs) (Fayette $95 \mathrm{~kW}$ and Nordtank $65 \mathrm{~kW}$ ). The site and machine characteristics are summarized in Table 4.

The expected results of each project were detailed, simultaneous upwind and downwind velocity measurements and turbine power measurements within operating wind farms for correlation with the results of existing wake models and previous work at PNL.

\begin{tabular}{|l|c|c|c|l|}
\hline \hline \multicolumn{1}{|c|}{$\begin{array}{c}\text { Study } \\
\text { Turbine Type }\end{array}$} & $\begin{array}{c}\text { Site } \\
\text { Location }\end{array}$ & $\begin{array}{c}\text { Crosswind } \\
\text { Spacing }\end{array}$ & $\begin{array}{c}\text { Downwind } \\
\text { Spacing }\end{array}$ & $\begin{array}{l}\text { Terrain Complexity, } \\
\text { Slope, and Fetch }\end{array}$ \\
\hline \hline $\begin{array}{l}\text { Fayette } \\
\text { Fayette 95-kW HAWT }\end{array}$ & $\begin{array}{l}\text { Castello Ranch, } \\
\text { Altamont }\end{array}$ & 3 & $10-11$ & $\begin{array}{l}\text { Relatively flat, less } \\
\text { than 2० slope, clear } \\
\text { fetch }\end{array}$ \\
\hline $\begin{array}{l}\text { FloResearch } \\
\text { FloWind 150-kW VAWT }\end{array}$ & $\begin{array}{l}\text { Cameron Ridge, } \\
\text { Tehachapi }\end{array}$ & 3 & 8 & $\begin{array}{l}\text { Relatively flat plateau, } \\
\text { about } 7^{\circ} \text { slope, fetch } \\
\text { includes 1200' rise } \\
\text { from Cache Creek }\end{array}$ \\
\hline $\begin{array}{l}\text { Altamont } \\
\text { Nordtank 65-kW HAWT }\end{array}$ & $\begin{array}{l}\text { a) Jess Ranch, } \\
\text { Altamont } \\
\text { b) Souza Ranch, } \\
\text { Altamont }\end{array}$ & 2 & 9 & $\begin{array}{l}\text { Relatively flat, less } \\
\text { than 2 slope, fetch } \\
\text { includes rolling hills } \\
\text { and canyons }\end{array}$ \\
\hline $\begin{array}{l}\text { Moderately complex, } \\
\text { gentle rolling hills, } \\
\text { from 7 to 12 }{ }^{\circ} \text { slope, } \\
\text { fetch includes a } \\
\text { canyon }\end{array}$ \\
\hline
\end{tabular}

${ }^{1}$ In rotor diameters

Table 4. Site Comparisons - Wake Tests, Wind Turbine Configuration, and Array Spacing 
Fayette - Altamont Pass (Fayette 95-kW HAWT)

The test array was located on the Fayette Castello Ranch in the eastern portion of the Altamont Pass wind farm area in California (see Figure 10). The test array consisted of 35 Fayette model 95-IIs HAWTs in an orthogonal grid on a small plateau rising $100 \mathrm{ft}$ above the surrounding terrain and oriented perpendicularly to the prevailing westsouthwest flow. Lateral spacing of turbines within each row was three rotor diameters; downwind spacing was 10 to 11 diameters.

\section{Test Results}

Thirty-two hours of data indicated wake-induced energy production losses of $6 \%$ for turbines 10 rotor diameters downwind of one row and losses of $7 \%-8 \%$ for turbines downwind of two rows. Wake losses for low-rpm operation decreased with increasing ambient wind speed.

Losses for high-rpm operation were generally independent of ambient wind conditions. These figures are specific to the conditions present during the study and should be treated as approximate.

The following additional findings are also of interest.

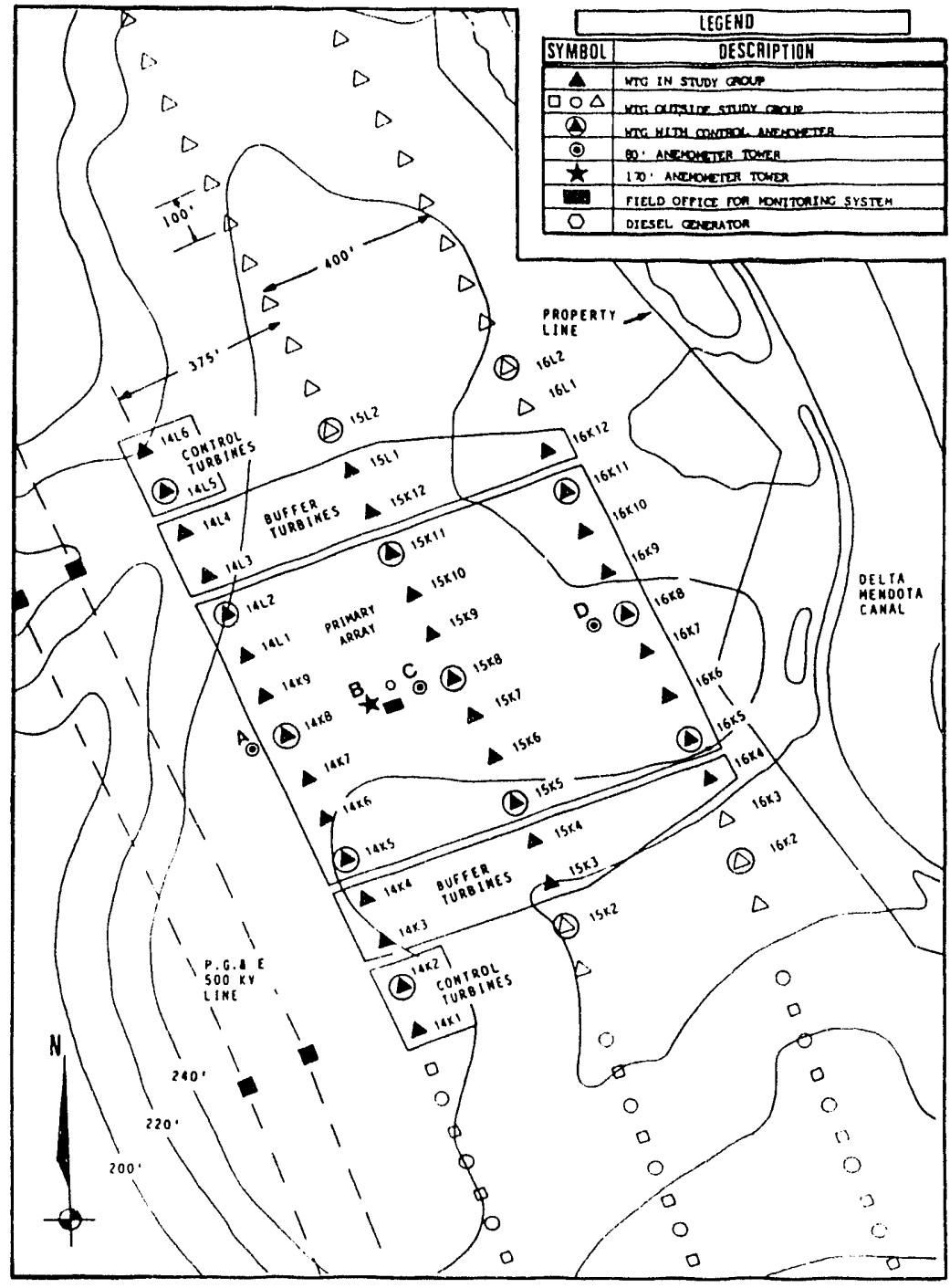

Figure 10. Location of wake-effects test array on the Castello Ranch
- Changes in ambient wind characteristics (such as vertical shear and turbulence intensity) were not found to affect the energy production losses.

- Horizontal and vertical wake growth sufficient to influence energy production in adjacent machines was not noted. 
- Anemometers supporting the second and third rows of the array were located at eight and nine rotor diameters downwind of the first and second rows, respectively. Mean turbulence levels at these distances were always identical whether or not the upwind rows were operating.

\section{FloWind - Tehachapi (FloWind 150-kW VAWT)}

The test array was located on the FloWind Cameron Ridge wind farm in the eastern portion of Tehachapi Pass, Calif., (see Figure 11). The nine 17-m Darrieus VAWTs in the array were arranged in an orthogonal grid, three turbines to a row, on a relatively flat portion of the ridge. Lateral spacing within rows was three rotor diameters. Spacing between rows was eight rotor diameters.

A variety of test configurations were used to evaluate row effects, single (or "primary") turbine effects, and "side turbine" effects.

\section{Test Results}

More than 150 hours of measurements were made of all planned wake configurations. The following effects were noted.

- For a single turbine wake, velocity deficits were found to be higher at lower wind speeds and under less turbulent conditions. The deficit decreased to zero in higher wind speeds $(>10 \mathrm{~m} / \mathrm{s})$.

- When the two turbines adjacent to the primary turbine were turned on in the presence of winds less than $10 \mathrm{~m} / \mathrm{s}$, the deficit increased with increasing speeds, perhaps due to vortex shedding. Above $10 \mathrm{~m} / \mathrm{s}$, no additional deficit was noted. Researchers concluded that ambient

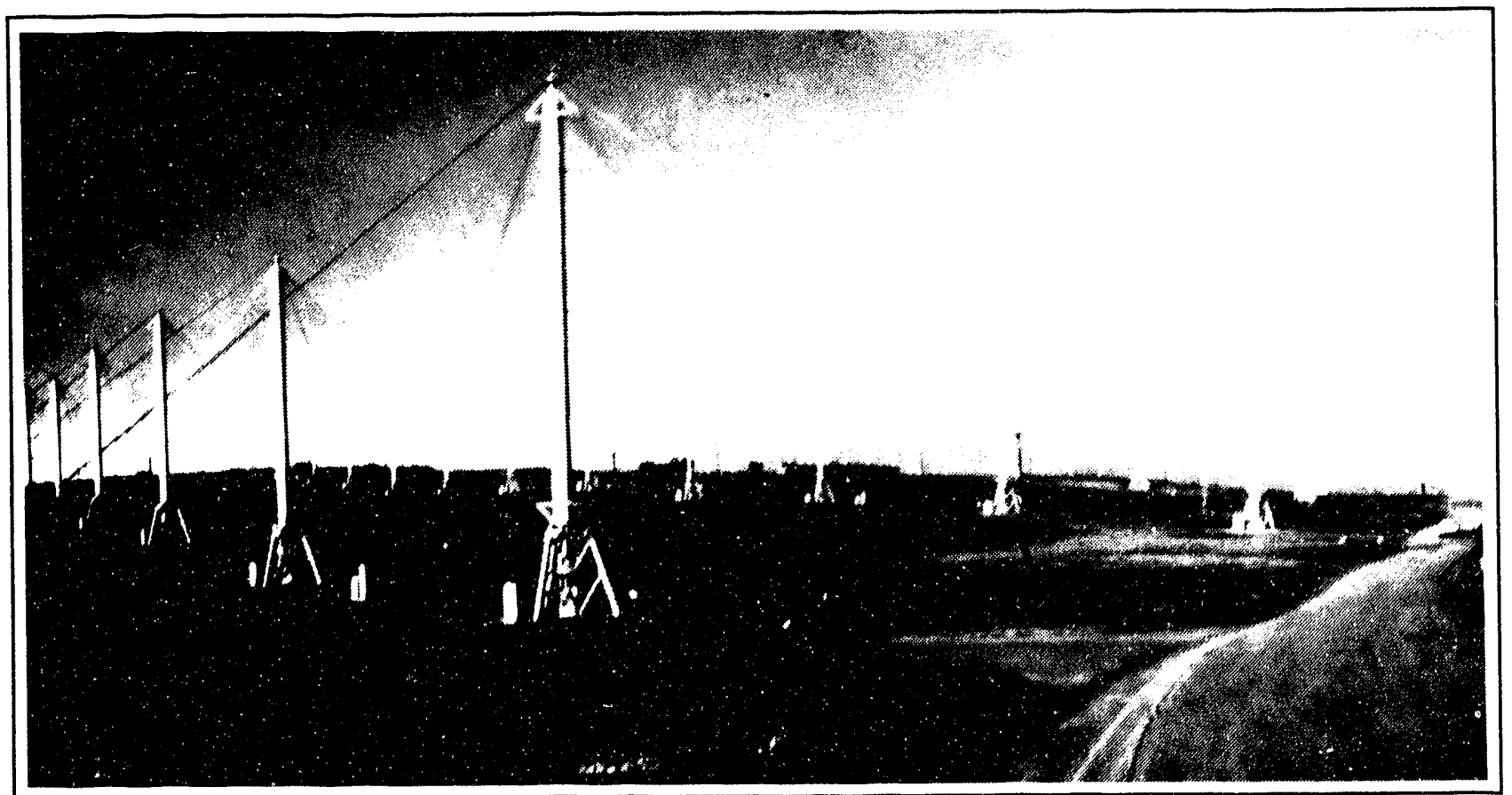

Figure 11. FloWind wind farm on Cameron Ridge, Tehachapi, Calif. 
turbulence becomes stronger in higher winds, while the blade-to-wind-speed ratio decreases. This reduces the effect of turbine-generated turbulence on downwind machines.

- Energy production deficits of $14 \%$ were measured in row two when only the primary turbine was operating in row one. These deficits increased to $20 \%$ when the two adjacent rnachines were turned on. (FloWind cautions that the measurements were taken during a moderate wind period, when deficits would be higher than high-wind periods. They calculated an annual deficit of $10 \%$ during a recent 12 -month period.)

\section{Altamont Energy Corporation - Altamont Pass (Nordtank 65-kW HAWT)}

There were two test sites for this project:

(1) the Jess Ranch in the eastern portion of the Altamont Pass area and (2) the Souza Ranch in the northern portion of the pass area. Thirty-seven Nordtank $65-\mathrm{kW}$ HAWTs were used at the Jess Ranch and 17 turbines of the same make and size at the Souza Ranch. The Nordtank is a three-blade, horizontal-axis machine with an upwind, stall-regulated rotor.

Seven different test configurations were used, ranging from a "blockbuster" test of the effect of two rows of turbines on one downwind row, to a "meandering wake" test of the effect of a single turbine on a row. A "sixteen-diameter" test measured the wake 16 rotor diameters downwind. A "direct wake" test measured the effect of a single upwind row on a single downwind row. A "multiple row wake" test was designed to measure the incremental wake deficits of one, two, and three rows of upwind turbines (see Figure 12). Other tests were conducted to measure the effect of adjacent turbines ("lateral wake") and

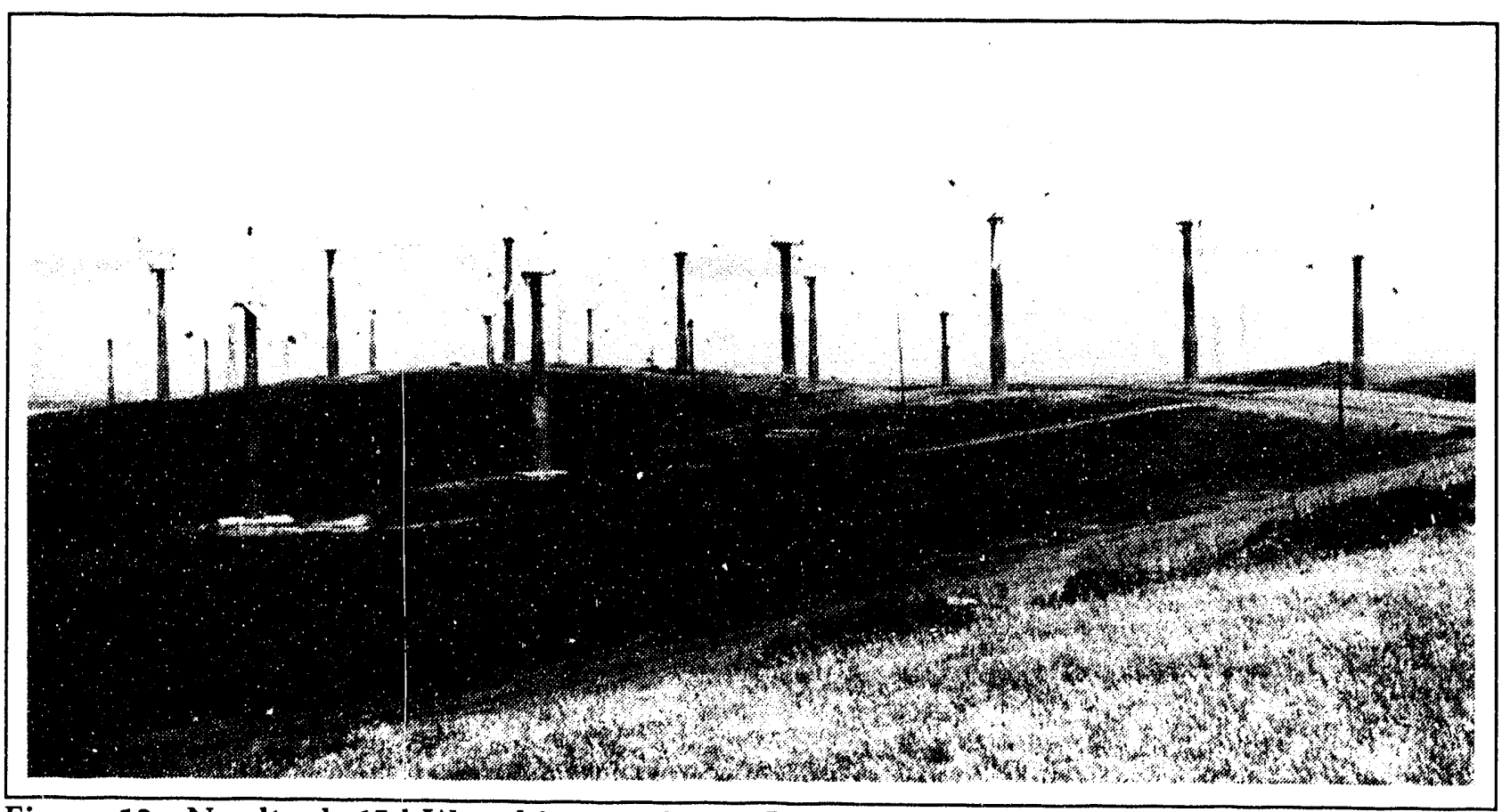

Figure 12. Nordtank 65-kW turbines at Souza Ranch (view from east) 


\section{Wake Measurement Tests}

the effect of winds blowing along the rows ("parallel wake"), where machines were spaced 1.9 rotor diameters apart.

\section{Test Results}

The greatest energy deficit was $50 \%$ for the "parallel wake" test. The lowest was $12.1 \%$ for the "sixteen diameter" test. However, the "direct wake" (eight-rotor diameter) results were almost identical to the far wake, with a mean deficit of $12.3 \%$.
Researchers speculate that the persistence of the wake may be due to the stable flow conditions and shallow flux layer at the site.

The more realistic tests-for closely spaced, multiple row farms-were the "blockbuster" and "multiple row" tests. An example of multiple row effects, showing terrain features and wind turbine row locations, is provided in Figure 13. The arrow in Figure 13 corresponds to the view

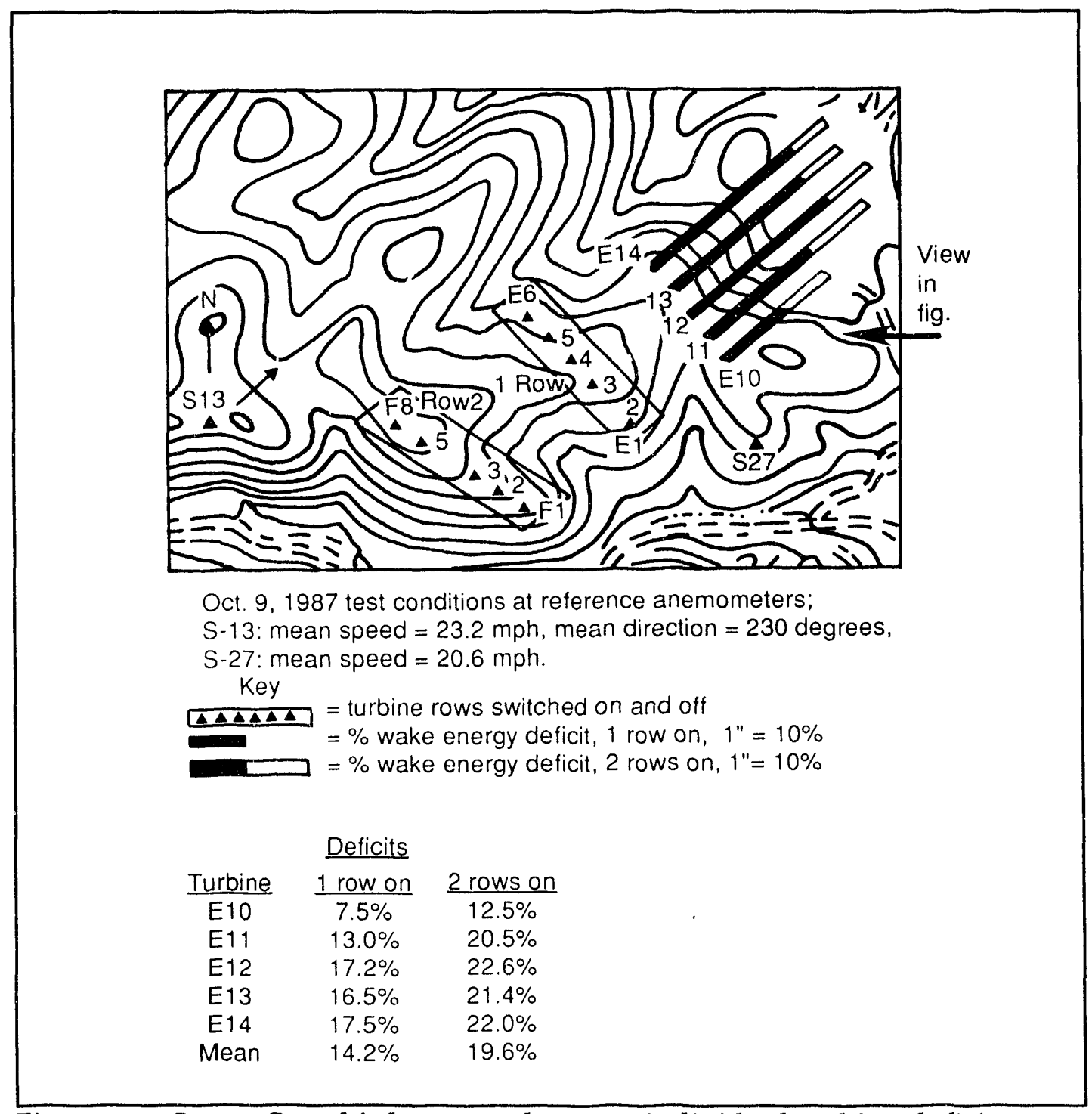

Figure 13. Souza-C multiple row wake test - individual turbine deficits 
of the site provided in Figure 12. Results of these tests can be summarized as follows:

- In the "blockbuster" test, which measured the effect of two rows on a downwind row, the relationship between wind speed and energy deficit was much more pronounced than the relationship for single rows. At relatively low winds, deficits of $25 \%$ were noted. A 10-mph increase in wind speed decreased the deficit to $6 \%$.

- In the "multiple row" test, the incremental wake energy deficits were $50 \%$ of the single row deficit in winds below $30 \mathrm{mph}$. In winds above $30 \mathrm{mph}$, the incremental wake deficit from the additional rows was negligible.

\section{Wake Measurement Test Conclusions}

A number of lessons were learned from the wake measurement tests.

- When considering the wake of one row of wind turbines, there is an inverse relationship between ambient wind speed and energy deficits in downwind machines, which is a function of the turbines' performance characteristic.

- The inverse relationship between wind speeu and energy deficit is more pronounced when the effect of the wakes from two upwind rows is measured. This is more $r \epsilon_{1}$ - esentative of the situation in an actual wind farm with multiple rows of wind turbines.

- Terrain effects, which may enhance or retard the ambient wind speed and dramatically change its turbulence characteristics, can have a significant impact on wake structures, compounding energy deficits within wind farm arrays.

Results of the wake tests are summarized in Table 5, which allows a comparison of wind farm configuration and velocity and energy deficits. These data characterize typical wind turbine sites in California. While the optimum wind turbine spacing can only be obtained by using a detailed siting model that includes an economic model, these wake effects data are necessary inputs to the development of such a model. 
Wake Measurement Tests

\begin{tabular}{|c|c|c|c|c|}
\hline \multirow[b]{2}{*}{ Study } & \multicolumn{2}{|c|}{ Losses Across One Row } & \multicolumn{2}{|c|}{ Losses Across Two Rows } \\
\hline & Velocity & Energy & Velocity & Energy \\
\hline Fayette & $\begin{array}{c}2 \%-4 \% \\
\text { (10 RD) }\end{array}$ & $\begin{array}{c}6 \% \\
(10 \mathrm{RD})\end{array}$ & $\begin{array}{c}4 \%-5 \% \\
(20 \text { RD) }\end{array}$ & $\begin{array}{c}7 \%-8 \% \\
\text { ('20 RD) }\end{array}$ \\
\hline FloResearch & $\begin{array}{c}5 \%-10 \% \\
\text { (8 RD) }\end{array}$ & $\begin{array}{c}14 \%-20 \% \\
(8 \mathrm{RD})\end{array}$ & $\stackrel{*}{*} \stackrel{(8 \mathrm{RD})}{ }$ & $\begin{array}{c}15 \% \\
(16 \mathrm{RD})\end{array}$ \\
\hline Altamont & * & $\begin{array}{c}12 \%-13 \% \\
\text { (8.5 RD) }\end{array}$ & * & $\begin{array}{c}16 \% \\
(17 \mathrm{RD})\end{array}$ \\
\hline
\end{tabular}

*Not measured.

$\mathrm{RD}=$ rotor diameter.

Table 5. Comparison of Wake Test Characteristics and Results 


\section{Free-Flow Micrositing Tests}

The primary objective of the "free-flow" measurements was to collect detailed wind measurements across sites considered appropriate for wind farms. The expected outputs were detailed wind speed and direction measurements, with corresponding analyses of wind speed distributions, turbulence intensities, wind shear, and wind turbine power output. The effects of prominent terrain features at the sites were of particular interest.

Free-flow measurements were made at the Whisky Run wind farm in Oregon by Pacific Wind Energy and at the Jess and Souza Ranch wind farms in Altamont Pass by Altamont Energy Corporation.

\section{Pacific Wind Energy}

The prominent terrain feature at the Whisky Run site was a 100 -ft bluff immediately upwind of the wind farm (see Figure 14). It was felt that the general effect of the bluff could be determined by comparing the wind speeds and wind turbine power outputs at various locations around the wind farm for different wind direction cases. Wind measurements at the site were referenced to anemometers on a 350-ft tower in the center of the wind farm. This tower had speed and direction sensors at 50, 80, 100, and $200 \mathrm{ft}$. Spatial wind variations were measured at three 80- $\mathrm{ft}$ towers (instrumented at $50 \mathrm{ft}$ and

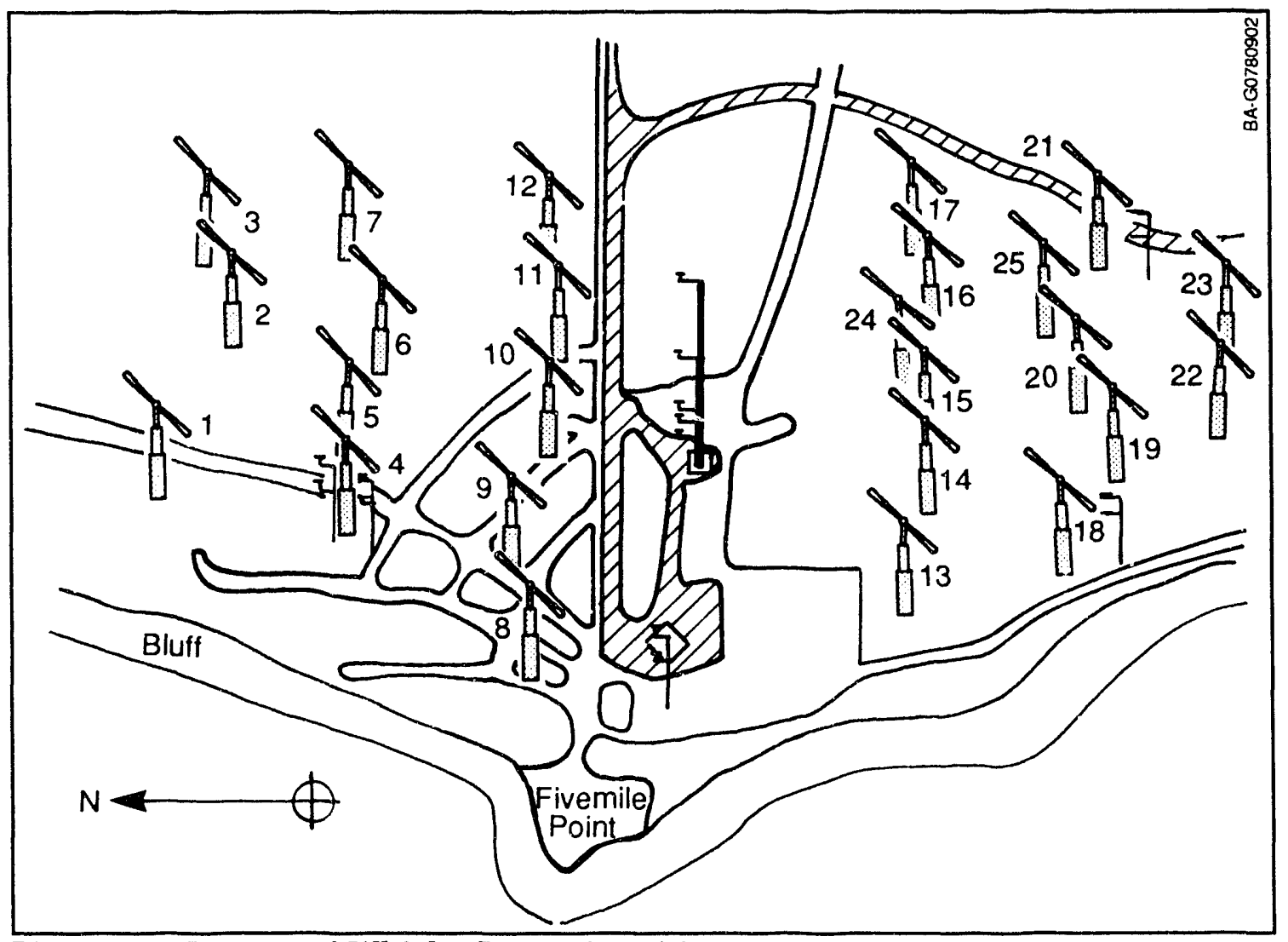

Figure 14. Layout of Whisky Run micrositing test 


\section{Free-Flow Micrositing Tests}

$80 \mathrm{ft}$ ) and at four turbines (instrumented at $50 \mathrm{ft}$ ). Fourteen anemometers at heights ranging from 50 to $200 \mathrm{ft}$ were employed. Some wind data had been collected before the wind turbines were installed.

Researchers hoped to compare wind shear and turbulence levels obtained then with new data collected in the prcsence of the wind farm. Hourly and 10-min average data were collected for 1 year.

\section{Test Results}

Researchers were able to use the meteorological and machine output data obtained at the site to draw some conclusions specific to the Whisky Run site and general hypotheses regarding all complex sites.

Since the installation of the wind farm, an increase in shear was measured between the 50- and 200- $\mathrm{ft}$ and 50- and 100-ft levels. The largest average shear increase (under southerly flows) was from 0.18 to 0.26 , calculated from $50-\mathrm{ft}$ to $200-\mathrm{ft}$ heights.

The results indicate that the wind speed distribution varies significantly throughout the year. However, the results also suggest that, in general, the shape of the wind distribution is almost constant with height.

The spatial variation of winds across the site ranged from $5 \%$ stronger (than the center of the wind farm) in the northwest corner to $11 \%-12 \%$ stronger in the southwest corner, due primarily to better exposure afforded by the bluff.

The diurnal variation of hourly ratios of wind speed (site speed versus reference site speed) is significant for some wind direction quadrants and barely evident for others. The large difference between daytime and nighttime ratios implies that short-term kite measurements, usually made during the day to relate one site to a reference site, may not be adequate for some conditions.

The most dramatic effects of the bluff on turbine performance were noted in the two turbines on the west border of the wind farm, near the bluff (turbines 4 and 18). When winds were westerly, both of these machines produced nearly twice the power for a given speed as turbines on the eastern border (turbines 7 and 21). However, slight shifts in wind direction across the bluff created noticeable performance changes depending upon whether the bluff accelerated or decelerated flow.

\section{Altamont Energy Corporation}

Altamont Energy Corporation employed five towers (seven anemometers) at the Jess Ranch and three towers (five anemometers) at the Souza Ranch. Including wind turbine anemometers, 77 and 28 wind speed measurements were made at the sites, respectively. No data were available from before the installation of the Nordtank wind turbines. The predominant feature of the Altamont Pass $u$ ind regime is its shallow, highly stable flow acceleration zone. Because of this feature, the applicability of test findings to sites in other geographical areas is limited.

\section{Test Results}

On the Jess Ranch, wind speed varied $\pm 23 \%$, with corresponding energy variations of $\pm 32 \%$. Variations were caused by drainage canyons and a $150-\mathrm{ft}$ hill upwind of the site. While the terrain at the Souza Ranch is more complex, wind speed ratios varied only $11 \%$, with a corresponding energy variance of only $10 \%$. Because the tests were not conducted simultaneously, it is not possible to correlate these results. The prominent 


\section{Free-Flow Micrositing Tests}

terrain features were drainage canyons parallel to the wind flow. These canyons appcared to enhance wind speeds and energy output during the measurements. The researchers caution that such features may not have similar effects in other wind regimes.

Wind shears were generally very low on well-exposed ridges and higher at more sheltered sites, ranging from 0.06 to 0.11 at Jess and 0.0 to 0.08 at Souza. No turbulence measurements were made.

\section{Free-Flow Micrositing Conclusions}

The free-flow measurements resulted in extensive data sets with high site-specific interest, but little applicability to other sites or wind regimes, with the exception of sites near bluffs similar to those of the Whiskey Run wind farm. The measurements did confirm general observations about the sites and demonstrated the high degree of wind speed variability that can exist across a single wind farm. The microsite data are high quality and would be useful for comparison with predictions made by existing free-flow models, such as NOABL. 


\section{Wind-Hybrid System Tests}

\section{Bergey Small Wind Electric Pumping System Tests}

In a small wind electric pumping system (SWEPS), a high-speed, low-solidity wind turbine is connected electrically to a motordriven centrifugal pump (see Figure 15). The wind turbine operates at a variable speed and produces a variable voltage, variable frequency, three-phase $A C$ output from its alternator. This output is connected directly to a three-phase induction motor that drives the pump. The pump operates at a variable speed that is determined by the wind speed. SWEPSs do not require the batteries and static power inverters used in conventional wind electric pumping systems.

Potential advantages identified for the SWEPS include high operating efficiency, siting flexibility, improved reliability, and large capacities. The objectives of this project were to begin the process of verifying these advantages by (1) determining whether available electrical pumps would be suitable for this application, (2) obtaining test data on a series of SWEPS configurations, and (3) developing an analytical model for use by SWEPS designers. Both laboratory and field tests were conducted. Dynamometer tests in U.S. Department of

\section{Dar El Hamra Equipment Layout}

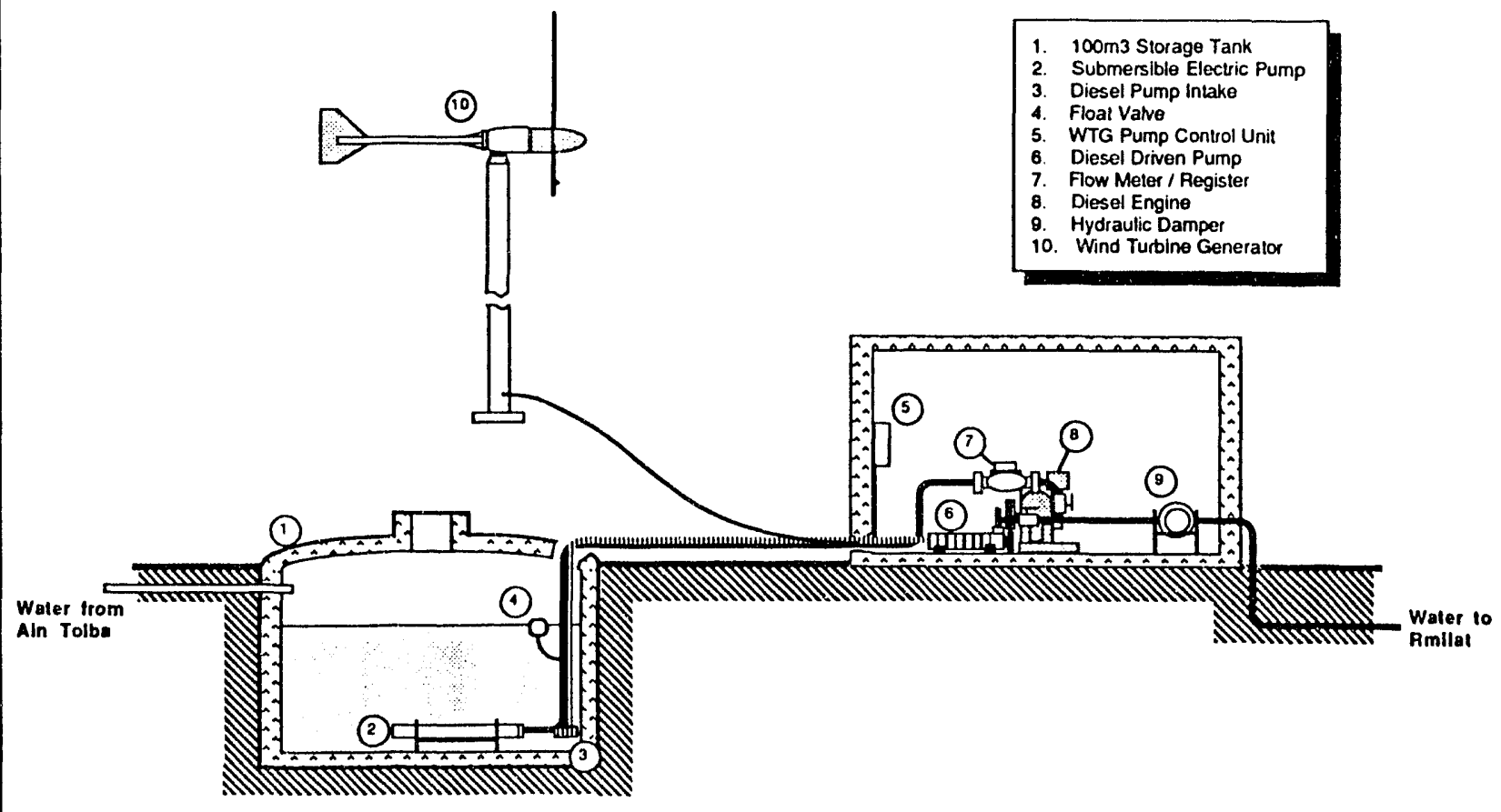

Figure 15. Schematic of a SWEPS installed at Dar El Hamra, Morocco, subsequent to CFTP research 
Agriculture, Agricultural Research Service (ARS), Bushland, Texas, used standard, commercially available, single-stage and multi-stage centrifugal pumps with power supplied by wind turbine alternators. For field testing at ARS a Bergey EXCEL 1000 wind turbine $w$ ith an identical alternator was used. Pump performance baselines were established by operating the pumps directly from utility power. The tests were conceived to determine the effect of variable speed and widely variable frequency operation $(25-100 \mathrm{~Hz})$ on the operating characteristics and efficiencies of several types of electrical pumps designed for constant-speed operation.

\section{Test Results}

The dynamometer tests indicated that the constant-speed alternator/pump combinations functioned well under variable speed and variable frequency operation. For example, the alternator for the SINEPS-1 pump operated at efficiencies of $65 \%-70 \%$ at frequencies below $30 \mathrm{~Hz}$.

This increased to efficiencies of $75 \%-85 \%$ at frequencies above $40 \mathrm{~Hz}$. These figures are comparable to alternator efficiencies achieved in other small wind turbine applications, such as battery charging. At the same time, the pump efficiencies were in good agreement with the manufacturer's data at 50 and $60 \mathrm{~Hz}$, and only slightly lower at lower and higher frequencies. The pump efficiencies remain fairly constant over a wide range of water flow rates. Based on the combined motorpump efficiency data (see Figure 16), Bergey Windpower concluded that a SWEPS would operate at satisfactory pump efficiencies over a wide range of head and flow conditions.
Field tests were conducted of three SWEPS configurations using three different water pumps: a Berkeley B3ZRM pumping into a static head of $2 \mathrm{~m}$, and two submersible pumps, a Grundfos 80550 pumping into a static head of $20 \mathrm{~m}$, and a Grundfos SP4-42 pumping into a static head of $80 \mathrm{~m}$. Flow rates for the various configurations are depicted in Figure 16. Of particular interest is the relatively low wind speed at which the systems begin operation. Given the low solidity of the electrical output wind turbine, cut-in speed was one area of concern prior to the field tests. Given this concern, an automatic control system was constructed to operate a three-phase contactor between the turbine and the pumps. The controller allowed the turbine to start up unloaded and then applied the pump load at a frequency in the range of $28-40 \mathrm{~Hz}$. It also disconnected the pump at a frequency of $80-100 \mathrm{~Hz}$.

\section{Northern Power Systems Wind-Hybrid Research}

The NPS research program focused on understanding the value of hybrid power system architectures to telecommunications and remote village users. The objective of the project was to answer the major technical questions concerning component performance and system interaction as well as developing an analysis tool that would facilitate engineering and implementation of these power systems.

This project tested a new architecture for wind-diesel systems that uses a synchronous generator as a synchronous converter to allow a wind turbine induction generator to remain on line without the diesel generator operating. The system architecture combines the power systems on the DC bus, where the load distribution and 
Wind-Hybrid System Tests

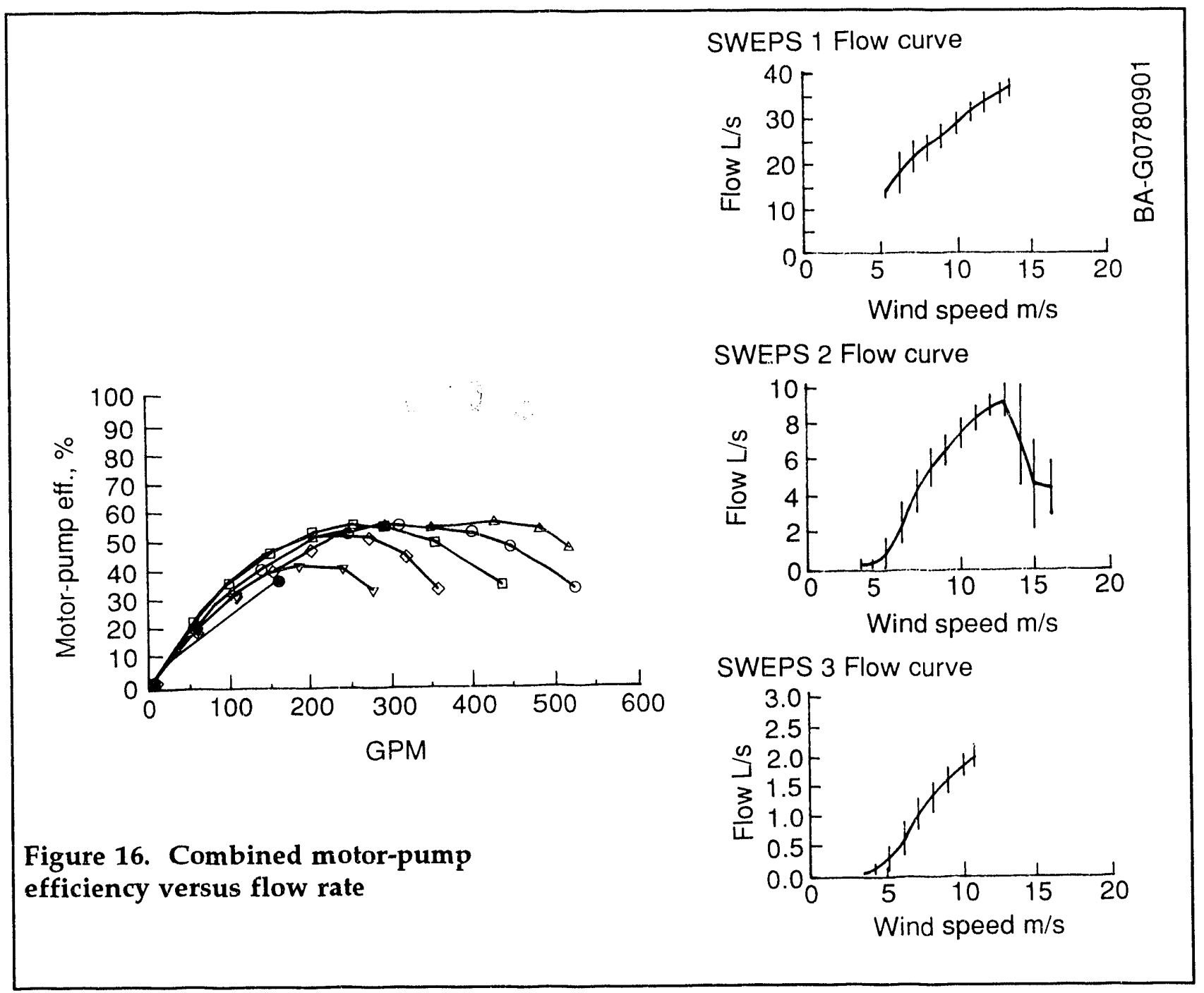

battery storage are also located. The architecture is depicted in Figure 17.

The approach to the research was to simultaneously obtain remote site test data from instrumented wind-hybrid sites and to perform laboratory tests of similar systems to create generalized computer codes that would predict wind-hybrid system performance. The generalized computer analysis code was developed based on the laboratory test data. This code was then used to review the remote site data, with the ultimate test of its accuracy being its ability to predict the remote power system performance.

\section{Test Results}

The greatest advantages of the new system architecture to telecommunications and remote village power systems derive from allowing the diesel generator to be shut off for extended periods. This allows for the greatest fuel savings, while ensuring that the diesel generator does not have to operate under partial or changing load, either of which will reduce the efficiency, 


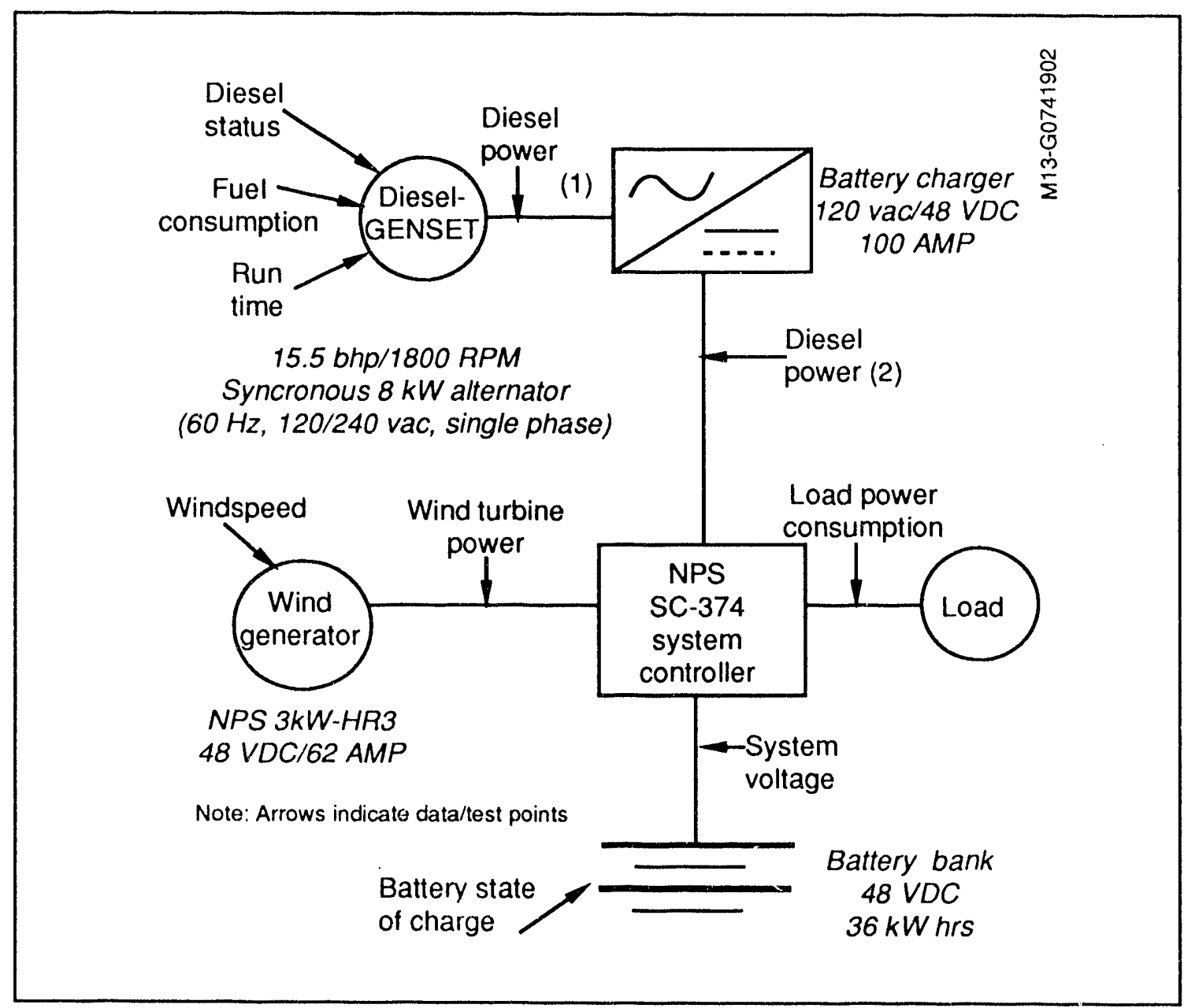

Figure 17. Northern Power Systems wind-diesel architecture schematic

reliability, and life of the engine. For each application, the NPS research verified the ability of the wind-hybrid architectures used to shut off the diesel generator.

\section{Laboratory Tests - Wind-Diesel-Battery System}

The NPS design philosophy is to turn on the diesel in advance of the battery reaching a low state of charge. This period is typically thought of as the response time of the service personnel. This allows time for personnel to intervene if the remote monitoring equipment indicates that the diesel is malfunctioning.
Laboratory tests were performed to provide a consistent set of data to illuminate two important factors in wind-diesel design: (1) determining the appropriate end-of-charge cycle to turn off the diesel when the batteries are fully charged and (2) the extent to which the two changing systems (wind and diesel) interact.

\section{Telecommunication System}

Figures 18 and 19 provide data illustrating the operation of the wind-hybrid telecommunication system at Ivanoff Bay, Alaska, showing wind turbine and diesel power production and corresponding battery voltage and charge data. The data 
Wind-Hybrid System Tests

collected during a 6-month observation period indicate that the diesel was only required to run about $28 \%$ of the total 150 hourseither when the wind turbine was not operating due to low winds or when extended wind turbine operation allowed battery voltage to drop below a preset level. Note also that the diesel was able to run at virtually full power during this time, maximizing its efficiency and minimizing wear.

Atlantic Orient Corporation Wind-Hybrid Stability and Penetration Study

Atlantic Orient Corporation (AOC) explored the effects of high wind energy penetration levels on wind-diesel system voltage and frequency stability through a systematic series of tests. The practicality of designing a simple, lowcost system using

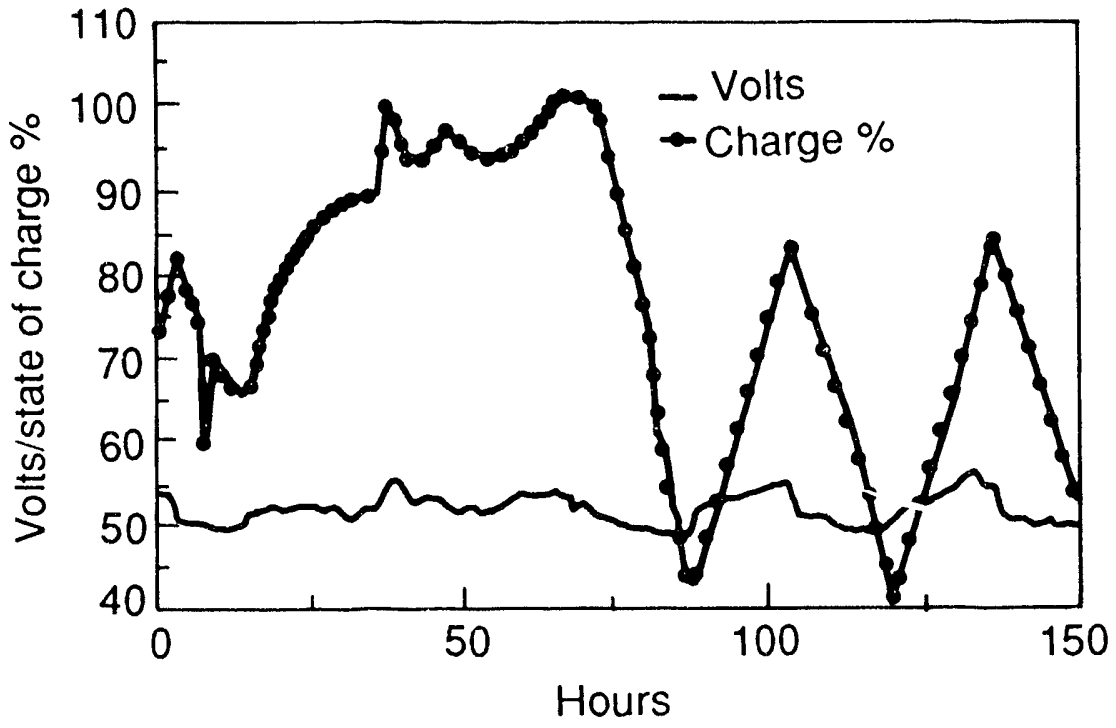

Figure 18. Battery voltage and charge data-Ivanoff Bay, Alaska

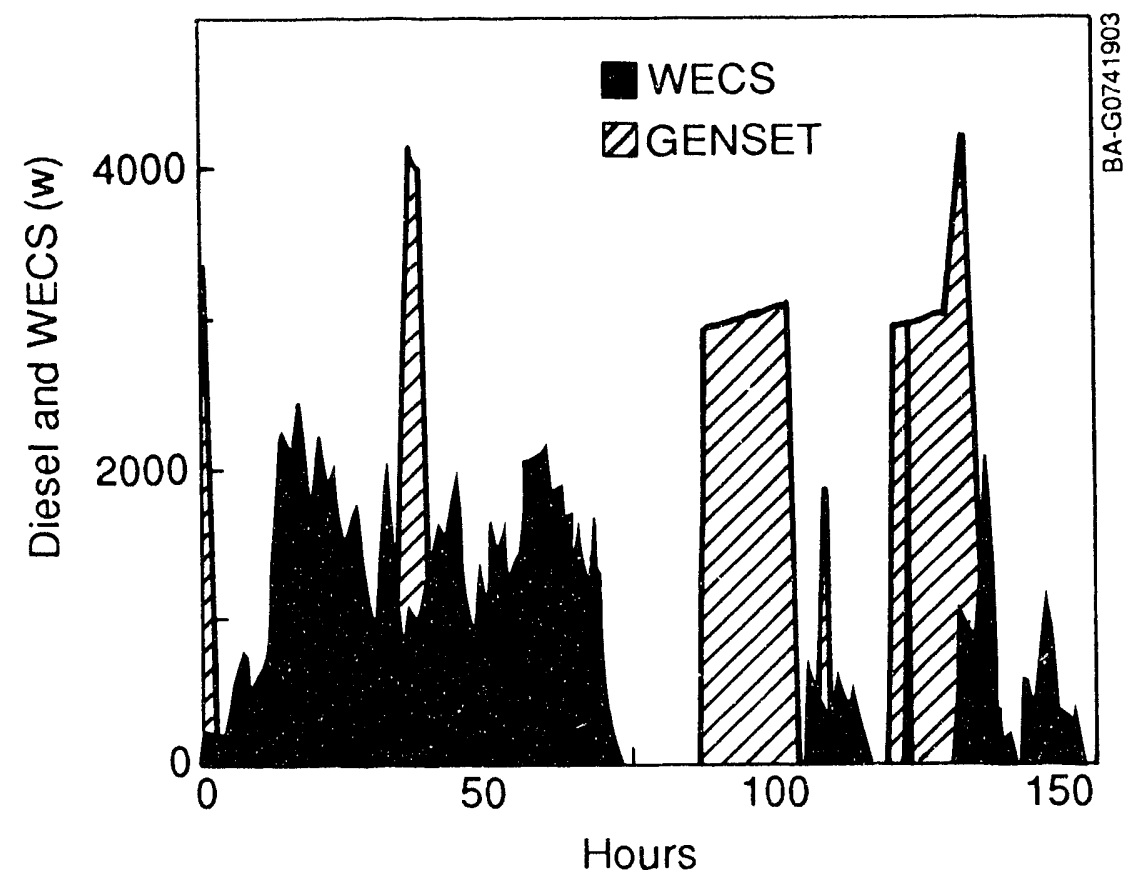

Figure 19. Wind turbine/diesel power production 
only the diesel to control voltaged frequency was also explored. The intent of the investigation was to develop a data base for the effective design of wind-diesel generating systems that maximizes the contribution of wind energy.

Tests were conducted at the AOC facility in Norwich, $\mathrm{Vt}$. The test configuration included $30-$ and $90-\mathrm{kW}$ diesel generators; a $25-\mathrm{kW}$, engine-driven wirid turbine induction generator that simulates a wind turbine; a resistive load bank; inductive loads; and a data acquisition and control system. No storage was included. The setup is illustrated in Figure 20.

The tests conducted included baseline fuel consumption tests for the 30- and $90-\mathrm{kW}$ diesel generators and tests of the diesel generators with simulated wind turbine input. The test approach for the simulated wind turbine input was to establish the operating limits for a potential windhybrid system by simulating a variety of incidents and situations that would cause system problems, measuring the diesel's ability to control the loss of voltage and frequency instabilities that were created. The tests consisted of the following.

- Back-drive - Power from the simulated wind turbine induction generator was raised gradually with observation of the degradation of frequency and voltage. No resistive load.

- Near instability - System ran at very high levels of penetration for an extended period (2-3 $\mathrm{min}$ ) and effects on voltage and frequency monitored.

- Step inductive load - An unloaded 30-hp induction motor was switched suddenly into the grid while a resistive load of $75 \%$ of grid capacity was connected to the system bus. Fifty percent of power provided by simulated wind turbine.

- Phase loss - With the simulated wind turbine generator operating at a high penetration level, one of the three phases was dropped to observe the effect on system stability.

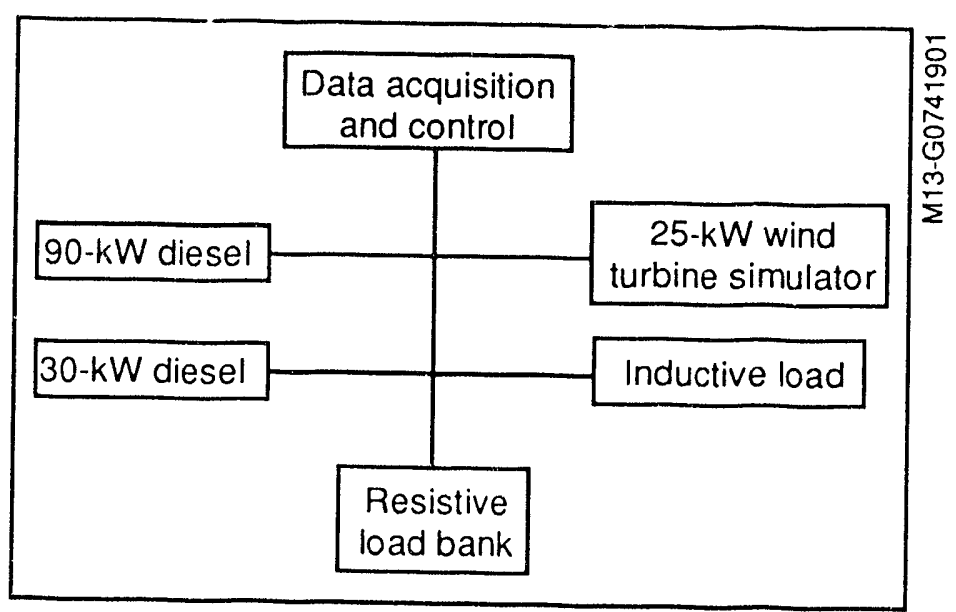

Figure 20. Wind-hybrid system test configuration

\section{Test Results}

The study revealed no insurmountable problems associated with winddiesel system stability and penetration. Resistive loads were switched on and off in response to system characteristics and were found to be an effective and simple way of maintaining system stability. 
Backdrive tests demonstrated that an extremely simple control strategy for frequency and voltage may be employed for a simple wind-diesel system. During the $90-\mathrm{kW}$ backdrive test, for example, frequency was held within $\pm 1.5 \mathrm{~Hz}$ and voltage within $6 \mathrm{~V}$ while the diesel absorbed up to $35 \mathrm{~kW}$ of the simulated wind turbine output.

Excess capacity or dump loads may also be provided as a backup to the backdrive technique, providing greater controllability in some cases. Dump load tests were conducted for both the $30-\mathrm{kW}$ and $90-\mathrm{kW}$ diesels. For the 90-kW diesel, step-by-step increases and decreases in resistive loads were added to control frequency, while maintaining wind turbine power output at a constant $45 \mathrm{~kW}$. Figure 21 shows the incremental changes in the resistive load for the diesel configuration using an electronic diesel governor. Figure 22 illustrates the high degree of control exhibited over system frequency (during the resistive load changes shown in Figure 21) using this configuration.

While using the diesel to control the system is relatively straightforward, AOC researchers concluded that it is important to fully characterize loads prior to developing a system-specific control strategy. As system load grows and changes in character over time, the control strategy may have to be modified to assure continued stable system operation. The AOC tests demonstrated that a simple, highpenetration, no-storage wind-diesel system is technically feasible.

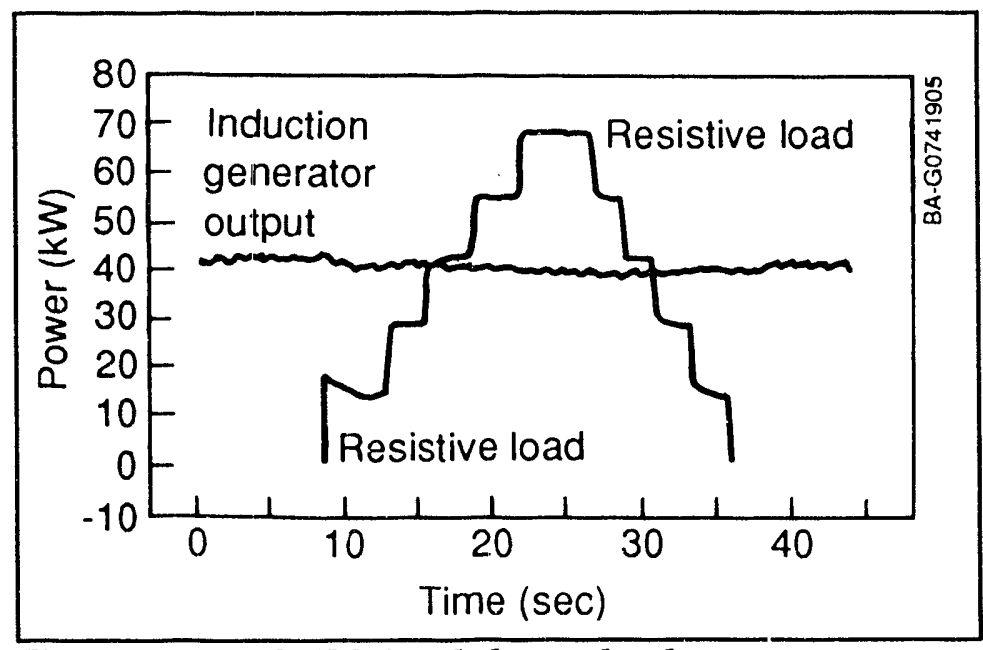

Figure 21. 90-kW Diesel-dump load power

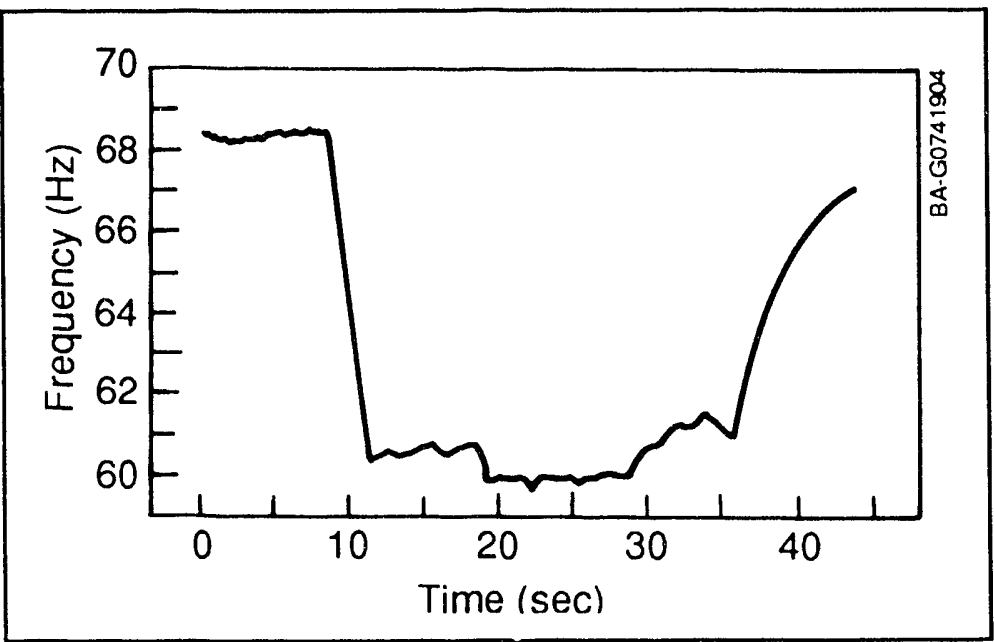

Figure 22. 90-kW Diesel-dump load frequency control 


\section{Program Accomplishments}

The primary goal of the CFTP and CRP was to obtain data from actual operating turbines and wind farms that would be useful in the validation of existing analytical tools and in solving industrial technical problems. This goal has been met. The machine data sets provided by the CFTP were the first high-quality data sets that accurately characterized the intermediate-scale HAWTs of primary interest to U.S. industry and the research community. Micrositing and wake data have been and continue to be equally pertinent and valuable. Second-round agreements demonstrated that advanced wind-hybrid applications are feasible. Wind-diesel tests provided designers and users with new insights regarding the controllability and potential for high system penetration of these systems. In addition, development of a new electrical water pumping configuration was assisted, resulting in its being brought to the marketplace while the cooperative agreement was in place.

Research organizations are using machine data to validate yaw control models, turbulence models, and structural dynamics models. NREL has used the Howden and NPS dynamic response data to conduct revealing comparisons of rigid and flexible rotor system loads. Data from the siting studies are being used by two participants in the DOE Small Business Innovative Research Program. PNL will use the freeflow data for validation of their terrain models.

Industry is using dynamic response data to investigate several issues, including the yaw system design of the NPS North Wind 100 and the use of vortex generators on the Westinghouse $600-\mathrm{kW}$ machines. FloWind has used the wake measurement data to revise its anemometer control strategy for array start-up and shutdown. Altamont Energy Corporation has used its wake data to enhance the control and monitoring functions of the Jess Ranch and Souza Ranch wind farms.

The CFTP was among the first programs initiated by DOE to encourage broad-based technology transfer activities with the U.S. wind industry using cooperative research as a medium for communication. Industry enthusiasm in the program was high, as evidenced by their close technical involvement and cooperation and by the industry cost sharing, which exceeded $50 \%$ of the total cost of the program. Given the high technical and programmatic value of the CFTP to government and industry, additional efforts of this nature are highly recommended. 


\section{Bibliography of CFTP Reports}

\section{Bibliography of CFTP Reports}

Literature cited in this bibliography is of two types: (1) primary reports developed by industry participants in the CFTP and (2) reports and papers on research conducted using CFTP data. Raw CFTP data will not be published. However, data tapes are available from the National Renewable Energy Laboratory (wind turbine data) and the Pacific Northwest Laboratory (micrositing and wake data).

\section{Primary CFTP Reports and Papers}

Coleman, C., 1989, "Hybrid Power System Operational Test Results-Wind/PV/ Diesel System Documentation," Northern Power Systems, presented at the Windpower ' 89 Conference.

Coleman, C., 1990, Wind Hybrid System Research and Testing: Telecommunications Systems, Northern Power Systems, SERI/STR-257-3686.

Coleman, C., and McNiff, B., 1990, Dynamic Response Testing of the North Wind 100 Wind Turbine, Northern Power Systems, SERI/STR-217-3424.

Hughes, P.; Johnson, B.; Sherwin, R.; and Stern, W., 1990, System Stability and Penetration Study for Wind Diesel Hybrid Systems, Atlantic Orient Corporation, SERI, STR-257-3982.

Liu, H.-T., et al., 1988, Field Investigation of a Wake Structure Downwind of a VAWT in a Wind Farm Array, Flow Research Company, FloWind Corporation, SERI/STR-217-3370.

Nierenberg, R., 1989, Free-Flow Variability on the Jess and Souza Ranches, Altamont Pass, Altamont Energy Corporation, SERI/STR217-3404.
Nierenberg, R., 1990, Wake Deficit Measurements on the Jess and Souza Ranches, Altamont Pass, Altamont Energy Corporation, SERI/STR-257-3455.

Simon, R.L., Matson, D.F., Fuchs, J.M., 1987, Wake Effects in a Fayette 95-IIS Wind Turbine Array, Fayette Manufacturing Corporation, SERI/STR-217-3186.

Snow, A.L., Heberling II, C.F., Van Bibber, L.E., 1989, The Dynamic Response of a Westinghouse 600-kW Wind Turbine, Westinghouse Electric Corporation, SERI/STR-217-3405.

Walker, S.N., Wade, J.E., 1988, Effects of Precipitation on Wind Turbine Performance, Pacific Wind Energy, SERI/STR-217-3287.

Walker, S.N., 1988, Local Wind Measurements for Micrositing, Pacific Wind Energy, SERI/STR-217-3320.

Wehrey, M., Redmond, I., Anderson, C., Jamieson, P., 1988, Dynamic Response of a 330-kW Horizontal Axis Wind Turbine Generator, Southern California Edison and James Hoden and Company Ltd., SERI/STR-217-3203.

\section{Reports and Papers Using CFTP Data}

Hausfeld, T.E., Hock, S.M., and Thresher, R.W., October, 1987, "Preliminary Results from the Dynamic Response Testing of the Westinghouse 600-kW Wind Turbine," Windpower '87 Proceedings, SERI/CP-2173315.

Hock, S.M., Hausfeld, T.E., Hampsen, G., and Thresher, R.W., October, 1987, "Preliminary Results from the Dynamic Response Testing of the Howden 330-kW HAWT," Windpower '87 Proceedings, SERI/CP-217-3315. 


\section{Bibliography of CFTP Reports}

Hock, S.M., Thresher, R.W., and Wright, A.D., 1989, "A Comparison of Results from Dynamic-Response Field Tests," Eighth ASME Wind Energy Symposium.

Olsen, T.L., and Hock, S.M., 1989, "Data Analysis for Wind Turbine Dynamic Response Testing," presented at the IECEC Conference, Washington, D.C.

Olsen, T.L., and Hock, S.M., 1989, "Data Analysis Method for Wind Turbine Dynamic Response Testing," The 24th Intersociety Energy Conversion Engineering Conference.

Osgood, R.M., 1989, "SERI Data Systems for Analysis of HAWTs," Third National Conference on Microcomputer Applications in Energy.

Osgood, R.M., and Coleman, C., 1989, "A Comparison of Rigid Hub and Teetering Hub Operating Loads for the Northern Power $100 \mathrm{~kW}$ Wind Turbine," presented at the Windpower ' 89 Conference.

Osgood, R.M., and Hock, S.M., 1988, "Preliminary Field Test Results for the Northern Power Systems $125 \mathrm{KW}$ Wind Turbine," Seventh ASME Wind Energy Symposium.
Thresher, R.W., and Wright, A.D., 1989, "Prediction of Stochastic Blade Responses Using Measured Wind Speed Data as Input to the FLAP Code," Eighth ASME Wind Energy Symposium.

Wright, A.D., and Thresher, R.W., October, 1987, "Accurate Rotor Loads Prediction Using the FLAP Dynamics Code," Windpower '87 Proceedings, SERI/CP-2173315.

Wright, A.D., and Thresher, R.W., 1988, "A Comparison of Predicted Wind Turbine Blade Loads to Test Measurements," Journal of Solar Energy Engineering, No. 110.

Wright, A.D., Thresher, R.W., and Buhl, M.L., 1989, "Presentation of a Model for Predicting Wind Turbine Blade Loads and Response for Use on Personal Computers," Third National Conference on Microcomputer Applications in Energy. 

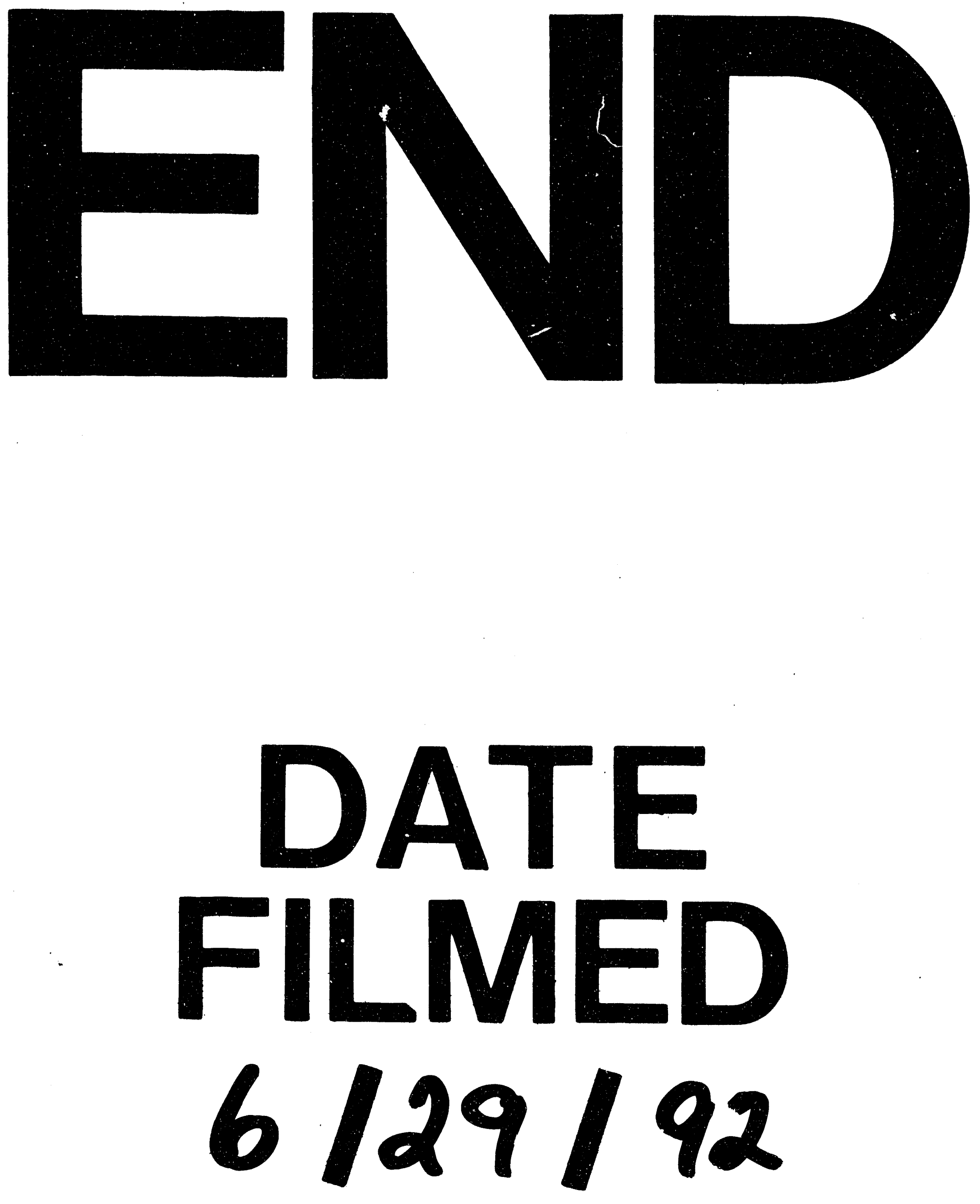
